\title{
TOWARD A BLACK LEGAL SCHOLARSHIP: RACE AND ORIGINAL UNDERSTANDINGS
}

\author{
Jerome MCCRistal CUlP, JR.*
}

\section{Prologue}

[FIRST WhITE PROFesSIONAL]: I mean-I didn't want to be like Ernie Banks. I wanted to be Ernie Banks.

[SECond White Professional]: $M r . C u b$.

[FIRST WhITE PROFESSIONAL]: And, it never really dawned on me that he was black, you know?

[SECond White Professional]: Wrist hitter.

[FIrSt White Professional]: I was, you know, seven years old. And he was just Ernie Banks. He was my hero.

[SECOND White Professional]: All in the wrists.

[FIRST White Professional]: There weren't any black people in my town. At least I don't think there were.

[Second White Professional]: Mister $\mathrm{Cub}$.

[FIRST White PROFESSIONAL]: Is it eight o'clock? Jeez, will you look at that. This is really something, huh? Wander in here off the street. I mean if people would just sit down and talk like this more often.

[SECond White Professional]: Communication. That's what it's all about.

[Brother From ANother Planet: No response.]

* Professor of Law and Director of the John M. Olin Program in Law and Economics, Duke University School of Law. A version of this Article was prepared while I was the MacArthur Distinguished Scholar at the Joint Center for Political Studies, Washington, D.C., and is part of J. Culp, Rights Due Respect: The Economics of the Legal Regulation of Employment Decisions (unpublished manuscript). The opinions expressed are my own and do not necessarily represent the views of the Joint Center or the MacArthur Foundation which provided support for this research. This Article was presented to the Midwest Law Professors of Color on February 10, 1990, and I benefited from the comments made at that conference on this paper by Norman Amaker, Robin Baird, Linda Greene, Jim Jones, Joe Knight, Beverly Moran, and Leland Ware. I also would like to thank my colleagues for their helpful comments-particularly Kate Bartlett, Walter Dellinger, David Lange, H. Jefferson Powell, Christopher Schroeder, and John Weistart. In addition, in the Fall of 1989 I taught a course entitled "Black Legal Scholarship" as a Visiting Professor of Law at the University of Michigan School of Law and this Article is better due to criticism of some of the ideas in that forum. Finally, I would like to dedicate this Article to the memory of Clarence Clyde Ferguson whose example as scholar, diplomat, and teacher has been an inspiration to me. Thanks also to my research assistants, Gretchen Carré Nelli, Erika Keller, Ben Reiss, and Jason Kopelow. 
Conversation of two white professionals lost in Harlem with a black mute alien from another planet. ${ }^{1}$

\section{INTRODUCTION: AN AFRICAN-AMERICAN MOMENT IN THE LEGAL ACADEMY}

There are moments when obscure events and chance historical eddies come together for an instant, with startling and important results. Such a moment occurred when thirteen insignificant colonies sent unknown farmers and businessmen to Philadelphia-delegates who impudently signed a declaration of independence. Ever since that time the world has had to live with the innocence, arrogance, and the efforts of those people. Fanme Lou Hamer's refusal on behalf of the Mississippi Freedom Democratic Party to take token black seats at the Democratic National Convention in 1964, even though all the black people of Mississippi were tired and needed rest, is another of those occasions. For the legal academy, this is such a moment in history, an African-American Moment, when different and blacker voices will speak new words and remake old legal doctrines. ${ }^{2}$ Black scholars will demand justice with

1. Brother From Another Planet (John Sayles, A-Train Films 1983) (The tale of a black mute alien from another planet who lands on Ellis Island and tries to survive in New York City. He discovers love and the power of brotherhood and observes the condition of black people in a racist society.). This Article is about opening a dialogue between white and black colleagues. The Prologue suggests some of the difficulties that need to be avoided if such a dialogue is to take place. In contrast, the Epilogue is an example of a positive form of dialogue.

2. I should describe at the beginning of this Article the relationship between Black Legal Scholarship and Critical Race Theory. A small but growing number of scholars of color have started to criticize and develop a perspective on the law that is conscious of racial and gender concerns. I have learned much from scholars of color in this group. To name just a few people from whom I have learned: Derrick Bell, John Calmore, Paulette Caldwell, Kimberlé Crenshaw, Harlon Dalton, Peggy Davis, Richard Delgado, Linda Greene, Neil Gotanda, Lani Guinier, Angela Harris, Charles Lawrence, Mari Matsuda, john powell, Gerald Torres, Patricia Williams, and Robert Williams. I consciously chose the notion of "Black Legal Scholarship" to focus on issues of being black in American law and society that are different from, if often similar to, the problems that are faced by other people of color in society and sometimes by women. I did not mean to preclude the discussion of nonblack people of color or to presume to claim some priority of status in the world of color for black people, but I did mean to emphasize-in a way that many often do not-that being black is different from other ways of being in our society and legal system. I hope this Article will spur the growth and development of scholarship of color, of critical race theory in its broadest terms, and any and all attempts to look at race and color in their broadest senses by white scholars and scholars of color. I believe there are at least some important lessons to be learned from doing so by not simply treating all people of color the same. In particular, the notion of "other" embedded in the concept of the "minority" permits the definition of nonwhite in white terms. It is this account of "other" that I reject by claiming to be black. See ANTHONY BARTHELEMY, Black FACE, MALIGNED RACE (1987) (noting that the notion of color has a broad meaning in English literary settings; for example, the term "moor" is used in English literature to mean anyone who was not Christian, European, or Jewish and includes Asians, Native Americans, Africans, Arabs, and all muslims-accordingly a moor is "not a European Christian." Id. at 7, 10-17). 
equality and nonblack scholars will understand. Such moments, whether mere seconds or whole decades, sweep away the unprepared and the recalcitrant with the necessity of the instant. Those in the legal academy who cannot speak the language of understanding will be relegated to the status of historical lepers alongside of Tory Americans and Old South Democrats.

Legal scholarship remains one of the last vestiges of white supremacy in civilized intellectual circles. Literature, art, and occasionally even politics have been changed significantly by legal efforts, even as law itself has remained indifferent to the import of those changes. ${ }^{3}$ Most legal scholars, judges, and law students do not know that they approach

The second issue is related to the first: whether race is a useful concept in either its broad or narrow terms - a point made by Professor Barbara Fields in history and in a slightly different way by my colleague Bill Van Alstyne. Professor Fields has pointed out that at least in the historical setting race is a construct of historians. She noted that the biological differences between white ethnic groups are larger than the differences among American blacks and that the genetic basis of racial groups is largely discredited. She contends that historians have made too much of race in a historical context:

It is my intention to suggest that Americans, including many historians, tend to accord race a transhistorical, almost metaphysical, status that removes it from all possibility of analysis and understanding. Ideologies, including those of race, can be properly analyzed only at a safe distance from their terrain. To assume, by intention or default, that race is a phenomenon outside history is to take up a position within the terrain of racialist ideology and to become its unknowing-and therefore noncontesting-victim.

Barbara J. Fields, Ideology and Race in American History, in REGION, RACE, AND RECONSTRUCTION 144 (J. Morgan Kousser \& James McPherson eds. 1982). Certainly we run the risk in legal scholarship of race of making race transcend law and thereby missing the fact that race is a construct of society and not a natural phenomenon. However, even if race is just an ideological construct of society, it is a powerful force-playing as powerful a role as nationality for most residents of North America. Even if slavery were not a racial phenomenon and not the inevitable result of racial prejudice, it became so in this country, and the results on our legal system are profound. In addition, I would argue that race can be positively claimed as a way of culturally and individually defining oneself. In that sense race matters not as a western concept of otherness or strangeness but as a source of Jazz and communal feelings and notions of brotherhood that transcend negative definitions. I would like the Black Legal Scholarship that we do to reclaim, as best we can, those positive elements of race.

3. See, e.g., Black Aesthetics (Pio Zirimu \& Andrew Gurr eds. 1973) (literature); Stokley Carmichael \& Charles Hamilton, Black Power: The Politics of Liberation IN AMERICA (1967) (politics); HENRY LOUIS GATES, JR., FIgURES IN BlACK: WoRDS, SIGNS, AND THE "RACIAL" SELF (1987) (literature); August MEIER \& ElliotT RUDwiCK, BlaCK History AND The Historical Profession, 1915-1980, at 239-308 (1986) (history); EARL E. Thorpe, BlaCK Historians: A CRITIQue (1971) (history). Gunnar Myrdal stated this argument quite succinctly in talking about the legal system and the South:

Practically all public officials in the South are whites. The principle is upheld that Negroes should not be given positions of public authority even on a low level ....

In the policeman's relation to the Negro population in the South, there are several singularities to be observed, all of which have to be explained in the historical setting presented above. One is that he stands not only for civic order as defined in formal laws and regulations, but also for "white supremacy" and the whole set of social customs associated with this concept. In the traditions of the region a break of the caste rules against one white person is conceived of as an aggression against white society and ... that even minor transgressions of caste etiquette should be punished, and the policeman is delegated to 
the question of law from a perspective that excludes black concerns. Most believe that American law, as derived from the Constitution and incorporated in the Declaration of Independence, deserves the respect, reverence and support of all Americans-particularly black Americanswho have benefited so directly from the beneficence of the current legal system. ${ }^{4}$ This beneficence, however, has been true more in theory than in

carry out this function. Because of this sanction from the police, the caste order of the

South, and even the local variations of social custom, become extensions of the law.

Gunnar Myrdal, American Dilemma 535 (1962) (footnote omitted). The system Myrdal described has changed im the South to a certain degree. However, he underestimates the extent to which caste exists in both the North and the South, and the fact that changes in the legal system have not accommodated themselves to the race-based caste system that exists in America. One can no longer contend that only whites are police officers, but blacks are still vastly underrepresented in the police forces of America in both the North and the South. For a discussion of McCleskey v. Kemp, 481 U.S. 279 (1987), see infra notes 139-45 and accompanying text. Note that it is still possible for counsel to withhold testimony of a black lawyer for fear that his assistance might have an "ill effeet" on the trial of a white defendant. See Burger v. Kemp, 483 U.S. 776, 814-16 (1987) (Blackmun, J., dissenting).

4. One of the best examples of this strong current in judicial opinions is Justice Bradley's opinion in The Civil Rights Cases, 109 U.S. 3 (1883), in which he concluded that the Civil Rights Acts cannot extend to the private activities of citizens, and thus helped to ensure that there would be no governmental proteetion for black civil rights until the second half of the 20 th century. Justice Bradley argued that,

When a man has emerged from slavery, and by the aid of beneficent legislation has shaken off the inseparable concomitants of that state, there must be some stage in the progress of his elevation when he takes the rank of mere citizen, and ceases to be the special favorite of the laws, and when his rights as a citizen, or a man, are to be protected in the ordinary modes by which other men's rights are protected.

Id. at 25. A recent statement of this view was made by Dean Eugene V. Rostow in his testimony in support of the nomination of Judge Robert Bork. Dean Rostow testified,

No one could have heard or read the testimony of some of the witnesses-Barbara Jordan, for example, or William Coleman-without being moved and troubled. They are concerned about the possibility immense progress in our constitutional law of personal liberty accomplished by the leadership of the Supreme Court since the time of Chief Justice Hughes would be placed in jeopardy by the appointment of Judge Bork. Such a possibility would indeed be a matter for universal alarm. But their fear is groundless.

Similar fears were widely held about the revolutionary changes in constitutional law which were expected during Chief Justice Burger's term of office. That revolution did not take place then, and it will not take place now. The development of law has immense momentum. It grows according to its own rules, case by case, generation after generation. It will prevail once again. The libertarian tradition of American society reinforced by its law does not belong to either political party or to any one intellectual or ideological sect. It is a national creation and a national possession made by thousands of men and women over the years, Republicans, Democrats, Federalists and Whigs alike; Liberals, Conservatives, and Radicals; judges, citizens, writers, political leaders.

Nomination of Robert H. Bork to be Associate Justice to the Supreme Court of the United States: Hearings on the Confirmation of Judge Robert Bork before the Senate Judiciary Committee, 100th Cong., Ist Sess. 1822 (1987). Dean Rostow suggested the existence of a neutral constitutional machine and did not include blacks among the creators of this constitutional edifice precisely because he believes that race, separate from the fact of being a conservative or liberal, or citizen or judge, cannot be relevant to American law. See also NATHAN Glazer, Ethnic DilemMas 19641982, at 159-232 (1983) (affrmative action and the voting rights acts benefited black people). Charles Murray argued that affirmative action has encouraged employers to hire highly edueated blacks, but does not force employers to the provide on-the-job training that leads to wage growth for white workers. Murray suggested that blacks are given opportunities that, because of their age and 
practice. 5 In fact, the American legal system's treatment of African Americans is a strange amalgam. Although it began by providing for extensive intrusion by the state into the private affairs of individual slaveholders by prescribing in great detail exactly what was required of individual slaves and their masters, ${ }^{6}$ the system eventually evolved into one that limited, for almost one hundred years, the ability of the state to protect the interests of the descendants of these black slaves. ${ }^{7}$ The ability

experience, they do not deserve, and that they do not turn that opportunity into the appropriate learning situations. Murray did not explain how or why black workers or white employers should react this way. In particular, given the strong history of racism and sexism in the job market, why did white workers not adopt a similar strategy of laziness and sloth that some now attribute to blacks given this opportunity? Murray instead portrayed the black experience as unusual, and the black participants in some labor markets as interlopers who will not know how to respond to market opportunities. See Charles Murray, Losing Ground $89-92$ (1984).

5. See Randall Kennedy, A Reply to Philip Elman, 100 HARv. L. Rev. 1938 (1987) (stating that Elman's account of the Supreme Court's invalidation of segregation is unreliable and "bad reminiscence"); Randall Kennedy, Race Relations Law and the Tradition of Celebration: The Case of Professor Schmidt, 86 CoLum. L. REv. 1622 (1986) [hereinafter R. Kennedy, The Tradition of Celebration].

6. See, e.g., Winthrop D. Jordan, White over Black: American AtTitudes Toward THE NEGRO, 1550-1812, at 103-10 (1968). Alan Watson described the differences between English and Roman law in the following fashion:

English slave law possesses a public dimension in a way that is in sharp contrast with Roman law. Apart from "traditional" criminal law, the state and the other citizens at Rome were not much involved with the slave and the owner. For example, no one could interfere with a slave except at the master's instigation. If the slave ran away, his capture was the master's business. No citizen group was organized to find the runaway. On recapture, it was the master's business to decide whether and how severely the slave was to be punished. It was up to the master to decide what clothing the slave wore, how he was to be educated, the training he was to receive, and the work he was to do. The slave could make contracts with the master's permission, could live wherever the master wished, could indulge in whatever activities (which were otherwise lawful) that the master allowed. In contrast, in English America one might almost say that a slave belonged to every citizenat least he was subordinate to every white. Thus a slave off a plantation could be stopped by any white and questioned on his activities. Citizens were organized by law in patrols to recapture runaways. Penalties were laid down for each offense of running away; if within a certain time the master did not inflict them the state would. The government declared that only appropriate clothing was to be worn, and it might even determine what clothing was appropriate. The state intervened in the education of slaves even to the extent of prohibiting teaching them to read or write. Slaves could not buy and sell as their master wished, they could not live apart from the master whenever he wished, they could not keep horses, cattle, and pigs; they could not, even if the master would allow it, hire out their time. These rules did not apply at all times and in all colonies or states, but they do give the flavor of the general law.

alan Watson, Slave Law in the americas 66 (1989).

7. See The Civil Rights Cases, 109 U.S. 3 (1883); LAURENCE Tribe, American ConstituTIONAL LAW $\S 18-2$, at 1693-98 (2d ed. 1988). For the most conservative interpretation of this period, see James McClellan, The Judicialization of the American Republic, in THE JUdGes WAR: The Senate, Legal Culture, Political Ideology and Judicial Confirmation 61 (Patrick McGuigan and Jeffrey O'Connell eds. 1987). McClellan wrote,

The crushing military defeat of the Confederacy and the ensuing decade of political radicalism also ushered in an amendment that has changed the face of the Constitution and substantially altered the frame of government. This is the Fourteenth Amendment, which long ago outlived its usefulness and now threatens to pull down the remaining pillars of the original Constitution. During the Reconstruction period, when this Amendment was 
of the American legal system to transform itself so completely in order to ensure the subordination of African Americans demonstrates that when the issue is race, all other interests take precedence-at least for most of the first 175 years of our constitutional history. ${ }^{8}$

This strange history has produced an even stranger reaction from both black and other scholars who are interested in bringing the experience of black Americans into the discussions of judges, law professors, and students. Until recently, black scholars in legal academia failed to create a distinct black legal scholarship. In this Article, I begin a threepart discussion about the development of this black legal scholarship. I first discuss the history of legal scholarship and blacks, and explain why black scholarship is only now becoming possible and what that means for the future of legal scholarship in this decade. Second, I explain how I think race enters into legal scholarship and discourse, and how the new black scholarship has raised and should continue to raise this issue. Finally, I discuss the limits of black legal scholarship.

The question of the proper role for black scholars is a difficult one. It involves issues of definition and seems to pose what for many black scholars becomes an almost impossible inquiry to answer-are we black scholars or scholars who happen to be black? The answer I provide in this Article is clear, if controversial. We cannot separate our blackness from the rest of ourselves. We are both black and scholars, and our blackness influences who we are, what we teach, and how we view the world. We can and do perform within some forms of traditional legal scholarship, but there are some assumptions that we cannot make about the world or how the world functions.9 We bring that notion of who we

forced upon the prostrate South, the Radical Republicans governed this country. Congress was king, and legislative supremacy was the law of the land. The Enforcement Clause of the Fourteenth Amendment, a strange and unique provision that promised to subvert the separation of powers by making Congress the judge of its own powers, was designed to serve as the vehicle for legislative supremacy. But Congress soon fell prey to internal difficulties and partisan bickering, and by 1875 the Supreme Court had taken full charge of the Fourteenth Amendment and its proper interpretation. Id. at 79 .

8. There are, of course, some exceptions to this trend. See Buchanan v. Warley, 245 U.S. 60 (1917) (holding that a municipal ordinance mandating that homeowners could not sell their homes to members of the minority race violated the fourteenth amendment); see also $\mathrm{R}$. Kennedy, The Tradition of Celebration, supra note 5.

9. This is true of almost all black academics despite divergent political views. Thomas Sowell, a conservative black scholar, does not believe that black Americans are intellectually inferior. On this point, he differs from some of the people who cite to his work with agreement. Compare Thomas Sowell, Race and I.Q. Reconsidered, in AMERICAN ETHNIC Groups 203-34 (T. Sowell ed. 1978) (noting that other ethnic groups now thought intellectually gifted, e.g., Poles, Jews and Italians, were once thought to be intellectually inferior) with ARTHUR JENSEN, BIAS IN MENTAL TESTING (1980) (arguing that blacks on average have lower I.Q.'s than whites because of genetic differences). Of course not all white conservatives subscribe to this view, either. 
are to the discussion, and it does not simply color the discussion; it infuses the discussion with our being. ${ }^{10}$

\section{From Mammies to Militants: The Role of Black SCHOLARS IN THE LEGAL ACADEMY}

\section{A. Introduction}

All black law professors face a common problem. We are asked to play a role that is assigned to us because of our race, and we then are asked to remove our blackness when we play the role. This role is to be black and to be a law professor without retaining any visible signs of our black experience. Our colleagues would like us to take care of black students, mother white students, and perform numerous tasks associated with being professors. ${ }^{11}$ Not all of us are ready or able to play all of the roles that our status as black representatives in a largely white profession thrust on us. We not only rebel, we try to reshape the role. With respect to our scholarship, we bring the voice of our own experience to the writing and teaching that we perform. Our experiences simultaneously vary from and are similar to the experiences of other black Americans. In addition, we are Americans, for the most part, born and educated, and certainly experienced, in the American society. We sometimes see the world exactly as other Americans see it and sometimes not, but we always bring that dual experience that is both similar to and different from the experience of white law professors to the jobs we perform as professors.

Despite these differences and similarities, we are asked to be responsible for responding to racial problems. When black students are harassed by representatives of large, mostly white law firms, we cannot escape being asked questions about what should be done. This occurs not only because we care about the answers our schools inake to such accusations, but also because our response is a check on the racism that we silently know exists in American society and certainly in the legal world. Similarly, few of us have escaped or can hope to escape the question, "What do you think of Randy Kennedy's article?"12 An even

10. There is a corollary to this point that applies with equal force to nonblack scholars, but I return to that point at the very end of this Article. See infra text accompanying notes 186-91.

11. See Derrick Bell, Strangers in Academic Paradise: Law Teachers of Color in Still White Schools, 20 U.S.F. L. Rev. 385 (1986); Roy Brooks, Life After Tenure: Can Minority Law Professors Avoid the Clyde Ferguson Syndrome?, 20 U.S.F. L. REV. 419 (1986).

12. Randall Kennedy, a black professor at Harvard Law School, argues that minority scholars have not proven that their views on civil rights were ignored by white scholars, nor have they shown in a traditional way that there is a racial critique that is unique to minority scholars. In addition, he claims that minority scholars who complain about diversity have failed to demonstrate that there is a sufficient pool of minority candidates to be hired at prestigious law schools. See Randall Kennedy, 
smaller number of us are able to escape being told what the questioner thinks is the correct answer to that question. It is in facing these questions that a part of the role of being a black law professor is defined.

The role of the black law professor is changing, and this change will shape how black law professors respond to these and other questions in the future. This role change is similar to the historical change that black workers have made over time. The best example of this phenomenon is the change in the portrayal of the black female domestic in literature and the movies from being mammies to being militants. ${ }^{13}$ This transformation reflects some real change in black doinestics as well as some real change in the perception of the rest of society. ${ }^{14}$

In the past, as black scholars we have been linited by our status, just as our grandmothers, inothers, and sisters were confined to work as inaids and wet nurses. ${ }^{15}$ White fainilies sought black woinen who could becoine larger-than-life mother figures, who coinpromised everything to be a part of the employers' world and thereby lost touch with black cominunities. ${ }^{16}$ Black woinen who were nuaids became "manmies" when they accepted the fate desired by the white households.

Racial Critiques of Legal Academia, 102 HARv. L. Rev. 1745 (1989); see also Colloquy: Response to Randall Kennedy's "Racial Critiques of Legal Academia," 103 HARV. L. Rev. 1844 (1990); Alex Johnson, "Racial Critiques of Legal Academia": A Reply in Favor of Context, 43 STAN. L. REV. 137 (1990); the debate and discussion associated with the Minority Section of the AALS that took place in Washington D.C. (Sept. 1989) (Richard Delgado, Kimberlé Crenshaw, Robert Williams, and Randall Kennedy) (audiotape available from author).

13. See Trudier Harris, From Mammies to Militants: Domestics in Black AmeriCan Literature (1982). Professor Harris looks at the changing role of black women domestics in American literature and describes the way in which these fictional characters become more faithful to their own lives over time; see also Donald Bogle, TOMS, CoONS, MULATTOEs, MAMmiEs, AND BUCKS: AN INTERPRETIVE History OF BLACKS IN AMERICAN FILMS (1973).

14. I choose this example self-consciously to include women as well as men. When I refer to black people in this Article, I mean both black men and black women with all that such inclusion entails as fully as it is possible to do so. I am reminded by Paulette Caldwell that there is a patriarchal interpretation of the notion of mammies and militants that I do not intend. I mean "militant" to convey an image of a militant black woman and "mammy" a nonmilitant black woman, and to have those woman stand for all black people in order not to avoid the role of women in the academy.

15. I believe my family's experience is typical of that of most black people of my generation. Every woman in my mother's generation at some time worked for a white employer in a household position. Black women of that era were overwhelmingly involved in household occupations. In my mother's family, black women started as mothers' helpers-positions that differed from being maids only in the pay-and at some point in their lives acted as a maid for a white employer. In 1958, more than 37\% of the employed African-American (black and other races) women worked as private household workers. See Handbook of Labor STatistics RefErence Edition, Table 19, at 68 (1975). Of course, not all black Americans have this experience. See Michelle Wallace, INVISIBILITY BLUES 13 (1990) ("My mother was never a domestic nor was any other woman in my family since slavery (they claim they were too 'proud').").

16. Trudier Harris described them this way:

Maids who are described as being truly southern are, then, those who generally acquiesce in the paternalistic and place-defined relationship between mistress and maid as it has been 
The image of the mammy has a positive meaning to many whites in the old South, but no black person today would accept that status-ivith its implications of subservience to white interests, ignorance, and lack of racial pride. Until recently, black scholars were, in many ways, in a position similar to that of black women, who were portrayed as mammies by popular culture, and who toiled in white households in the pre-1960 period in great numbers. ${ }^{17}$ Both groups were hard workers who had a limit (at least partially self-imposed) on what they could say to the white cohabitants of their world. They could not complain about the low pay or the hard work, or raise questions about the nature of the unwritten rules of their existence. Black legal academicians did not waste their time raising questions or providing answers if their colleagues on the faculty or the judge on the bench would not countenance them. Of course, there were always militants who cried in the wilderness about black problems, but they were not heard, were unlikely to be granted tenure, and little that they said or thought survives as part of the usable past. ${ }^{18}$

Black scholars knew, in exactly the way the black domestic did, that certain claims were outside the bounds of discourse. Some black maids came to believe in and endorse their status in white households, but for most, the role of mammy in white households was part of the duality of being black. ${ }^{19}$ For black legal scholars, as for black domestics, it is diffi-

shaped by the attitudes and traditions of southern society. Whether on northern or southern soil, they generally make few, if any, claims of dignity and self-worth within the established employer/employee relationship. They are more likely than the others to be "ideal servants," the mammy figures traditionally identified with southern plantation households. These women usually compromise everything of themselves and of their connections to the black community in order to exist in the white world.

T. HARRIS, supra note 13, at 23.

17. The notion of mammy and militant in this context has the dual advantage of including women in the discussion and not including notions of absolute subservience that are associated with other similar male concepts like Uncle Tom.

18. This problem of institutional amnesia still exists; the recent discussion about increasing the number of black faculty, see Paul Brest, Promoting and Nurturing the Academic Values of Faculty Diversity, AALS Comm. on Recruitment and Retention of Minority Law Teachers (Jan. 5, 1990), is uninformed by calls in the past by black faculty for similar efforts. See James Jones, Employment Discrimination, Minority Faculty and the Predominantly White Law School-Some Observations, 4 BLACK L.J. 488 (1975).

19. James Weldon Johnson describes this phenomenon in his 1912 fictional autobiography:

[T]his is the dwarfing, warping, distorting influence which operates upon each and every coloured man in the United States. He is forced to take his outlook on all things, not from the view-point of a citizen, or a man, or even a human being, but from the view-point of a coloured man. It is wonderful to me that the race has progressed so broadly as it has, since most of its thought and all of its activity must run through the narrow neck of this one funnel.

And it is this, too, which makes the coloured people of this country, in reality, a mystery to the whites. It is a difficult thing for a white man to learn what a coloured man really thinks; because, generally, with the latter an additional and different light must be brought to bear on what he thinks.... This gives to every coloured man, in proportion to his intellectuality, a sort of dual personality; there is one phase of him which is disclosed only in the freemasonry of his own race. I have often watched with interest and sometimes with 
cult to know when one has become the fictionalized character of the majority's imagination, rather than a real, if not always militant, nonfictional reality.

The black domestic in the pre-Brown v. Board of Education ${ }^{20}$ South who asked for too much was likely to have no job and possibly no life. Black scholars perceive similar restrictions, but have become more militant in their claims about the value of the black experience-only because those claims are countenanced by their colleagues. These black scholars hive in an uneasy peace with what their colleagues and judges hear and what they are willing to say. As black scholars make the transition froin maminies to imlitants, it is important to understand that the ability to be a militant is a product of historical opportunities (both societal permission and community strength), and not simply a matter of personal perseverance or courage. At the same time, it ought to be obvious that it is easier to inake the transition back from inilitant to mammy by acquiescing to the status quo. Today's militant is toinorrow's mammy to the extent that black scholars do not force legal scholarship and teaching to face up to the racism that lurks in our society. Such efforts are by definition awkward and unrewarding. And I should note that being black obviously does not equal being infallible. Black scholars are going to make errors and criticize improperly, but they cannot and should not be complacent about where they have been.

Black legal scholars have faced a history of not being heard, or of being heard only selectively. Like the inute alien in Brother from Another Planet, white scholars traditionally have heard black scholars only when what they have said and claimed were compatible with white concerns. Black legal scholars inust make the transition from producing scholarship exclusively directed toward whites in power to producing scholarship that is inwardly supportive of and directed to themselves, as well as to the whites and blacks in power.

\section{B. Black Jurisprudence and Black Legal Scholarship: From Mammies to Militants and Back Again}

1. Defining the Contours of Jurisprudence. Webster's Dictionary defines "jurisprudence" as being "a system or body of law," "the course of court decisions," or as "the science or philosophy of law."21 This

amazement even ignorant coloured men under cover of broad grins and minstrel antics maintain this dualism in the presence of white men.

James Weldon Johnson, The Autobiography of An Ex-Coloured Man 21-22 (2d ed. 1986) (emphasis added).

20. 347 U.S. 483 (1954).

21. WEBSTER'S THIRD NEW INTERNATIONAL DICTIONARY 1227 (1981). 
broad definition of jurisprudence, which encompasses two different concepts, obscures the different legacies of this term. I limit my use of the term "jurisprudence," to a description of the course of court decisions, and use the term "legal scholarship" to encompass the science or philosophy of law. 22 This distinction is crucial to my thesis that blacks have been somewhat successful in establishing a body of Black Jurisprudence through litigation and the presence of blacks on the federal bench. I believe that it is possible to discern a Black Jurisprudence in the opinions of the blacks who have been appointed to the federal bench in the last thirty years ${ }^{23}$ and in the efforts of blacks to change the views of white participants in the legal process. In contrast, however, blacks have produced very little in the realm of Black Legal Scholarship that challenges the underlying principles of a legal system that subordinates the needs of blacks to the interests of whites.

The primary objective of Black Jurisprudence has been to persuade the courts that legal rules ought to govern the relationship between blacks and whites. The history of Black Jurisprudence is the struggle to enlarge the arena in which legal rules apply. The black originators of the strategy to eliminate "separate but equal" laws had to use the primacy of legal rules in American society to persuade the courts that the legal rules that were applied to blacks were unfair. First, blacks had to prove that the law applied to them, and then they had to prove that the law ought to apply to them equally-that when it came to the application of the law, blacks and whites should be treated the saine.

The efforts of blacks to create a jurisprudence have evolved from a set of assumptions about the role of blacks and the black experience of the law that are very different from white perspectives. This jurisprudential difference has structured the arguments made by these black lawyers about the law and the Constitution. However, this Black Jurisprudence has focused on only one part of the difference between the black and the white legal experience-the denial of formal equality promised by the Constitution and denied to African Americans. The demand for equality

22. I have termed a similar distinction in theory the distinction between grand theory and parochial interest. The effort to find a grand theory is a growing effort in law-an effort to make law "scientific." Although not new, this effort has become increasingly important. See, e.g., George Priest, Social Science Theory and Legal Education: The Law School as University, 33 J. LEGAL EDUC. 437 (1983). In contrast, there is a growing effort to bring the parochial interests of women, racial minorities, and the poor into the legal discourse. This call to focus on these different concerns is reminiscent of older ways of legal discourse-a discourse in which theory played a much smaller role. See also Jerome Culp, Grand Theory and Parochial Interests: Black Perspectives and the Law (presented at Labor Law Section of AALS, San Francisco, January 5, 1990) (unpublished manuscript).

23. For an incomplete list of black judges now serving on the federal bench, see ON BEING Black: AN IN-Group ANAlysis 166 (David Pilgrim 2d ed. 1989) [hereinafter ON BeING Black]. 
with whites included a demand that blacks be recognized as the same as whites-the demand for "colorblindness." The claim that the Constitution and the American legal system in general is, or ever has been, colorblind or color neutral never has been attacked by Black Jurisprudence. This does not mean that adherents of Black Jurisprudence were unaware of this truth, but rather that it was not, or perhaps more clearly could not be, expressed.

Black legal scholars-particularly in the 1950s, 1960s, and 1970swere constantly drawn away from developing such a legal scholarship by the pull to participate in the struggle of black Americans for "equal justice under the law"-the cry for formal equality. Thurgood Marshall, Robert Carter, Constance Baker Motley and countless black attorneys in small towns were involved in the frontline claims for justice within the white system, according to white rules that hid white superiority under the claim of color neutrality. This effort to achieve equal justice through the court systein is really a request to those in power, largely white and male, to respond to black claims of justice. Black scholars liad to "know their place" in order to have their claims lieard. Black scholars and lawyers who participated in the mainstream of the profession supported the role that this "place" required of black scholars. Black scliolars were not the pure southern mammies of literature, but they were actors constrained by the understanding that making militant claims about change would not be countenanced by judges, white colleagues, or their largely white students.

Many of the black scholars who were attracted to the acadeiny were proponents of a Black Jurisprudence; with this orientation, they brought to legal scholarship the very arguments of "colorblindness" that they used in litigation. ${ }^{24}$ This lack of a separate and distinctly black legal scholarship seems strange given the long history of differential treatment of blacks in American society. The failure to deal with the entire spectrum of differences between blacks and whites has meant that the impact of the legal system on blacks, particularly the silent impact, has gone unrecorded in the very legal scholarship directed at explicating this situation.

2. Why Black Legal Scholarship? The focus on Black Jurisprudence has meant that a true Black Legal Scholarship has been woefully underdeveloped. Black legal scholars initially had to struggle for the victories in the courtroom under existing law before a distinct vision of the

24. See, e.g., William Ming, Racial Restrictions and the Fourteenth Amendment: The Restrictive Covenant Cases, 16 U. CHI. L. REv. 203, 237 (1948) (giving as an example of constitutional colorblindness the majority opinion in that case) [hereinafter Ming, Racial Restrictions]. 
law could be created. In creating a consistent perspective that they could use to litigate successfully in the courts, the black lawyer-proponents of Black Jurisprudence, both as litigants and as judges, accepted aspects of the vision propounded by the nonblack inajority. Black Legal Scholarship requires the articulation of visions that transcend these inajority perspectives.

The first and most important task of this Article is to convince black and white readers that there is a Black Jurisprudence and that this jurisprudence is leading to the developinent of a Black Legal Scholarship-a scholarship that ought to be included in the developinent of legal principles. White scholars often have ignored or belittled the contributions and efforts of blacks during the last thirty years. ${ }^{25}$ More is written about Earl Warren than about Thurgood Marshall, ${ }^{26}$ and very hittle attention has been paid to the large number of able black judges who now inhabit the federal trial courts and the courts of appeal in both the North and the South. ${ }^{27}$ The reason is quite simple: It is difficult for black people to be heard speaking on anything but race. Even when black scholars and lawyers are heard, the general public only understands a part of what black people say. In other words, like the accidental visitors to the Harlem bar in Brother From Another Planet, white scholars have concluded that they are having a conversation when they are really engaging in a monologue.

25. See Derrick Bell, Foreword: The Civil Rights Chronicles, 99 HaRv. L. REv. 4, 52-54 (1985) [hereinafter Bell, Foreword]; R. Kennedy, A Reply to Philip Elman, supra note 5; see also Richard Delgado, The Imperial Scholar: Reflections on a Review of Civil Rights Literature, $132 \mathrm{U}$. PA. L. REv. 561 (1984) (arguing that white scholars should stop writing about minority issues to leave room for minority voices).

26. This may explain why a random survey of American judges by the National Law Journal found that only three percent ranked Thurgood Marshall as the most admired Supreme Court justice-lower than any other justice, including Justice Scalia, who had been on the Court for only one year at the time of the survey. Only three percent of the sample surveyed were black. Ellen Rosen, The Nation's Judges: No Unanimous Opinion, Nat'I L.J., Aug. 10, 1987, at S1, S9. This view is consistent with the description of Justice Marshall in BoB WOODWARD \& ScOTT ARMSTRONG, THE BRETHREN 47, 77 (1979). Randall Bland argued that Marshall had a profound impact on the law primarily as an advocate: "[B]y any reasonable standard of objectivity, a review of the sixty opinions contributed by Marshall during his first four terms discloses a noticeable lack of judicial scholarship. In the main, his opmions included many, usually lengthy quotations from cited cases; they presented precious little original thought or distinguished conceptualizations." RANDALL BLAND, PRIVATE PRessure on PUBLIC LAW 174 (1973) (footnotes omitted). This view of Marshall as being unscholarly in many ways falls into the typical stereotype of blacks and is part of the effort to ignore Marshall's accomplishments as a judge and an intelleet. But see Symposium: A Tribute to Justice Thurgood Marshall, HARV. BLACKLETTER L.J., Spring 1989 (examining the role and intellectual accomplishments of Justice Marshall before and during his tenure ou the Supreme Court).

27. See, e.g., Richard KLUGER, SImple JUSTICE (1977) (a historical account of the progress of racism and black Americans in the law). Some things have been written about Justice Marshall, but, given his contribution as litigator and as judge in developing the law, the scholarship has been extremely limited. See also JACK BASS, UNLIKELY HEROES (1981) (the development of a group of white judges interested in equal justice in the South was unlooked for and unexpected). 
It is not that blacks cannot coinnunicate in any form, but like the mute in that movie, they cannot coinniunicate in a inanner that the white participants are currently able to appreciate. ${ }^{28}$ White liberals say that black scholarship does not exist outside of the coninion front that they have shared with black Americans. The efforts of blacks to free theinselves is considered derivative of the effort of white people to save them. In other words, the civil rights struggle is seen and understood through the eyes of the white people who participated in it. ${ }^{29}$ This way of seeing the civil rights struggle is less threatening to white interests, and it is consistent with other historical patterns of dealing with change. In his book, The Liberal Tradition in America, Professor Louis Hartz notes that Americans often believe that they are radical, although they actually suppress the inost important radical elements in the changing nature of the political process. ${ }^{30}$ This masking of the radical elenients has been particularly prevalent with regard to the issue of race and the law.

Those at the intellectual extreines also have ignored the efforts of blacks in the legal struggle. ${ }^{31}$ Radicals would like to redefine the struggle of blacks in their own terms, i.e., to subsunie blacks into a larger inodel of class struggle. ${ }^{32}$ Conservatives are more honest about their views on

28. This is not a new phenomenon. Free blacks before the Civil War created alternative abolitionist organizations and publications because they thought white abolitionists were not listening to their views. Leonard Sweet writes that

[M] any white[ ] [abolitionists] were both anti-slavery and anti-slaves. . . . Although aboli-

tionist patterns of action were not fissured neatly along racial lines, black abolitionists up-

held a vision of society ... . based not just on the abolition of slavery but on the annihilation

of race prejudice and the affirmation of equal rights and equal justice.

LEONARD I. SWEET, BLACK IMAGES OF AMERICA, 1784-1870, at 140-41 (1976).

29. See R. Kennedy, A Reply to Philip Elman, supra note 5, at 1938. Randall Kennedy argued that Philip Elman has ignored and belittled the efforts of black lawyers in the campaign to win Brown, and that Elman's efforts at history have degenerated into self-congratulation. Philip Elman stated that there is no need to respond to charges that he has belittled black lawyers because "[t]he answer to that is my entire life." Philip Elman, Response, 100 HaRv. L. Rev. 1949, 1957 (1987).

30. Louis Hartz, THE Liberal Tradition in AMERICA: AN INTERPRETATION OF AMERICan Political Thought Since the Revolution 3-32 (1955).

31. See Richard Delgado, Critical Legal Studies and the Realities of Race-Does the Fundamental Contradiction Have a Corollary?, 23 HARv. C.R.-C.L. L. REV. $407-13$ (1988); Andrew Haines, The Critical Legal Studies Movement and Racism: Useful Analytics and Guides for Social Action or an Irrelevant Modern Scepticism and Solipsism?, 13 WM. MiTCHELL L. REV. 685 (1987).

32. See Roberto UNGer, The CRITICAl Legal Studies Movement (1986); Critical Legal Studies Symposium, 36 STAN. L. REV. 1 (1984). Blacks are largely ignored by white radicals, except when they are discussing race. In addition, even when race is mentioned, white radicals often go out of their way to assign no power to race outside of class and other concerns. See, e.g., MARK KELMAN, A Guide to CRITICAL Legal Studies 247-49 (1987) (analyzing the response of Critical Legal Studies literature to the use of state force by elites); Frances Ansley, Stirring the Ashes: Race, Class and the Future of Civil Rights Scholarship, 74 CoRnell L. Rev. 993 (1989). Professor Ansley argues that there are two different models that describe the way of looking at race and the law: the race model, which sees racism as a product of the desire by society for white supremacy; and the class model, which sees racism as a product of class structure and power. However, both models 
race and about the contribution of blacks to legal scholarship. Because conservatives consider race irrelevant, blacks cannot have any clann on whites through their scholarship or arguments.

3. The Search for Color Blindness and Black Jurisprudence. Black Jurisprudence is a product of the efforts of a relatively small group of mostly black lawyers to achieve legal equality for black Americans. In partially reaching this goal, the participants argued for a model of equality that was a product of the dominant view of justice, but, in so arguing, they iguored other black concerns. This focus on bringing blacks within the protection of the law was often described in terms of color blindness. In 1955, Roy Wilkins, executive director of the NAACP, cominented on the then-recent victory in Brown, and described Black Jurisprudence as "the most vital ingredient in a government of, by and for the people, not the white people, but all the people."33

Frederick Douglass, the foremost black spokesperson in the 19th century, also adopted a Black Jurisprudential perspective. Speaking during the Civil War to a convention of Black Americans, Douglass said, "In this department of human relations, no notice should be taken of the color of men; but justice, wisdom, and humanity should weigh alone, and be all-controlling." 34

assume that race is part of some overarching system that is not race dependent. Part of what some black scholars are saying is that race is more than simply class.

Black radicals may be subject to the same tendency to subsume race within other categories. William Julius Wilson argues that race has been supplanted by class as the most important factor in the creation of differences among blacks and whites. See WiLliam JuLius WILSON, THE DeclinING SIGNIFICANCE OF RACE (1980).

33. Roy Wilkins, The Conspiracy to Deny Equality, in Negro Protest Thought IN THE Twentieth Century 255, 262 (Francis Broderick \& August Meier eds. 1965). He also added,

Slowly in this fifty-eight years, we have lifted ourselves by our own bootstraps. Step by halting step, we have beaten our way back. It has been a long and tortuous road since the Dred Scott decision of 1857 which branded us as non-citizens and which, by the Plessy decision, gave the states and the nation as a whole the green light to treat us as they pleased. .. . Thurgood Marsliall, our general counsel, has outlined how we will use the courts. We shall contimue to use education and persuasion and moral pressure. Heartened by the support of millions of our white fellow citizens in all sections of the country, we welcome their participation in the crusade which is one not alone for us, but for our nation as $a$ whole. And we sliall use all the political power we can muster.

Id. at 257-62 (emphasis added).

34. Frederick Douglass, The Cause of the Negro People (address of the Colored National Convention to the People of the United States, October 4-7, 1864), reprinted in 3 THE LIFE AND WRITINGS OF FREDERICK Douglass (Philip Foner ed. 1952). Douglass added,

We believe that the higliest welfare of this great country will be found in erasing from its statute-books all enactments discriminating in favor or against any class of its people, and by establishing one law for the white and colored people alike. Whatever prejudice and taste may be innocently allowed to do or to dictate in social and domestic relations, it is plain, that in the matter of government, the object of which is the protection and seeurity of human rights, prejudice should be allowed no voice whatever.

Id. at 418 . 
Similar themes of Black Jurisprudence echoed through much of the traditional civil rights movement. This theme is especially apparent in the speeches of Martin Luther King, ${ }^{35}$ but it is also visible in the work of other blacks, even conservative blacks who did not participate in the civil rights struggle directly. Thomas Sowell, a conservative economist, expressed this view in these terms:

An attorney and former official of the NAACP Legal Defense Fund inadvertently revealed much of the evolution of that organization when he noted that by the mid-1960s "the long golden days of the civil rights movement had begun to wane," that the legal tools which it had developed "now threatened to collect dust."... In reality, the crusade for civil rights ended years ago. The scramble for special privilege, for turf, and for image is what continues on today under that banner and with that rhetoric. ${ }^{36}$

Sowell disagrees with the broad notion expressed by both Douglass and Wilkins about the scope of Black Jurisprudence, but his stateınent makes clear that he agrees with the notion of equal rights and equal privileges; it is when black activists call for "special" rights that Sowell disagrees with the thrust of black demands.

As described by Roy Wilkins, Frederick Douglass, and Thomas Sowell, Black Jurisprudence consists of two elements. It demands that legal equahty, as defined by blacks, be given to black citizens, and it requires that the law respond to black pleas for participation in the struggle to define and achieve this equality and notion of justice.

This view did not always provide even the barest sense of equality for blacks. ${ }^{37}$ Black groups seeking equality in the late part of the 19th and the early part of the 20th century accommodated themselves to the hostility of whites by introducing separate car legislation in several states. ${ }^{38}$ Similarly, blacks who wanted jobs or to have their children educated in public schools preferred segregated schools to no schools or jobs

35. See Martin Luther King, JR., Why We CaN't Wait (1964); Randall Kennedy, Martin Luther King's Constitution: A Legal History of the Montgomery Bus Boycott, 98 YALE L.J. 999 (1989) [hereinafter R. Kennedy, Martin Luther King's Constitution].

36. Thomas Sowell, Civil Rights: Rhetoric OR RealitY? 117 (1984) (footnotes omitted) (emphasis added).

37. This does not mean that this approach taken by black lawyers was not different from the arguments that white lawyers would have made, nor that in its time the notion that blacks had a right to claim rights was not in and of itself a revolutionary notion. For a discussion of how black lawyers like Charles Houston and William Hastie became involved in the legal battle for equality, see August Meier \& Elliott Rudwick, Along the Color Line: Explorations in the Black EXPERIENCE 128-73 (1976) [hereinafter A. MeIer \& E. Rudwick, Along the Color Line]. Meier and Rudwick discuss the difficulty faced by black lawyers, particularly in the South, of being heard and the argument consistently made by Houston as a black dean of a black law school that blacks must be involved in the defense of black rights.

38. Charles Lofgren, The Plessy Case 13 (1987) (describing how a black legislator sought to have the Virginia legislature establish a committee to seek separate cars for blacks). Lofgren also 
at all. ${ }^{39}$ When it was possible, many black leaders called for equal opportunities on a nonsegregated basis. ${ }^{40}$ This was particularly true of calls for job equality during times of high labor demand.

The case that best summarizes Black Jurisprudence is, of course, Brown v. Board of Education. ${ }^{41}$ Almost twenty years of planning by a group predominately comprised of black lawyers and headed by Thurgood Marshall and Charles Houston produced the legal argument that led to success in Brown. ${ }^{42}$ In Brown, the NAACP argued that segregation was imherently unequal. ${ }^{43}$ But Black Jurisprudence was already recognizable in the best known precursor to Brown, Plessy v. Ferguson. ${ }^{44}$ In Plessy, the Supreme Court held that state-mandated equal but separate accommodations on an interstate rail line did not violate the constitutional requirement of equal protection incorporated in the fourteenth amendment or the prohibitions against slavery in the thirteenth amendment.

Plessy, like Brown, was the product of an extensive campaign by a black group to elininate the oppression associated witl segregation legislation in Louisiana. The Louisiana Separate Car Act recently liad been passed over the vigorous opposition of black legislators. ${ }^{45}$ Homer Plessy

notes that black Congressman Robert Smalls of South Carolina did not object to blacks having "separate but equal" accommodations. Id. at 15.

39. See farold Cruse, Plural But Equal: A Critical Study of Blacks and MinoriTIES AND AMERICA's PluRAI SOC1ETY 12-17 (1987). According to Cruse, blacks would have supported the Blair Bill, which would have provided for extensive investment in public education in the South, even though the bill called for segregated schools. Cruse argues that the black masses were not committed to integration, but this argument tends to iguore the problem that blacks often had to take what was given. Also, it is clear that much of the action by black groups from the 1840 s forward was a demand for an end to segregation in public accommodations and schools. See, e.g., Louis Ruchames, Jim Crow Railroads in Massachusetts, in BLACKs IN WhITE AMERICA Before 1865, at 394 (Robert Haynes ed. 1972) (blacks opposed segregation in antebellum North); C. LoFGREN, supra note 38, at 28-51.

40. See, e.g, Roger Fischer, The Segregation Struggle in Louisiana 1862-77, at 61-87 (1974) (blacks fought to eliminate segregation on public trolleys after the Civil War). Post-Civil War black-dominated constitutional conventions (Black and Tan conventions) adopted public accommodation provisions that eliminated segregation in much of public life. See id. at 88 (discussion of provisions in Louisiana); see also Peggy Lamson, The Glorious Fallure 73-74 (1973) (public accommodation bill adopted by the South Carolina legislature).

41. 347 U.S. 483 (1954).

42. Mark Tushnet has argued that the strategy of the NAACP was much less planned than suggested by its portrayal in Richard Kluger's book SIMPLE JUSTICE, supra note 27. See MARK Tushnet, The NAACP's Legal Strategy Against Segregated Education, 1925-1950, at 144-48, 159-66 (1987). This criticism seems misguided. Most observers agree, however, that the desegregation movement was held together by the position of the NAACP efforts in the legal arena.

43. See Brief for Appellants in Nos. 1, 2 and 4, and for the Respondents in No. 10 on Reargument, Brown v. Board of Education, 347 U.S. 483 (1954).

44. 163 U.S. 537 (1896).

45. C. LOFGREN, supra note 38 , at 28. 
was picked to represent the challenge to the law because he was oneeighth black and his black ancestry was not discernable in his appearance. Plessy's argument was that the classification of him as black was arbitrary and that the exceptions to the Louisiana statute arbitrarily limited the scope of the situations in which blacks could travel with whites. Under the Louisiana statute, a black man-as defined by the railroad conductor-could not ride with his white wife, nor could a white mother ride with her children if the children were defined by the railroad conductor as black. Justice John Marshall Harlan argued that this did not even permit the black nurse who was accompanying a white adult to faithfully carry out her duty. ${ }^{46}$

The Louisiana statute was written in a completely color neutral manner. From the perspective of the black citizens of Louisiana, the problem with the statute was not its failure to be color neutral, but its view of the world from a white perspective. The statute, magnificent in its color neutrahty, mandated separate accommodations, and interfered with the ability of black Americans to enjoy their citizenship by implicitly branding them as inferior. The statute permitted the railroad conductor to decide the color of the passengers and to seek governmental assistance in enforcing the statute. This statute also gave the conductor the right to abrogate the common law duty to carry a passenger who failed to adhere to these legislative regulations. This provision gave the white citizens the power to define who was black and then assign the rights that were applicable to that designation.

The American Citizen's Equal Rights Association, a group that proinoted the challenge in Plessy, consciously attempted to attack this perspective by having a series of octoroons arrested for violations of the Louisiana Separate Car Act. ${ }^{47}$ The eight-man majority in Plessy was not able to see the statute as a license to define who was black because the Court defined the issue as whether Louisiana had the ability to classify people and then to apply distinctions to thein. The Plessy majority believed that the stigmatizing impact of this equal-but-separate legislation was in the mind of black people. This meant that race, like the law, was viewed through white eyes. Other statutes imposing a white perspective on black citizens also let the ethnocentrism of white society ooze into statutory provisions; for example, by permitting black nurses to accompany white travelers, but not allowing white nurses with black travelers.

The movement to achieve equality for blacks accepted the notion of some black legislators who urged the adoption of separate car legislation

46. Plessy, 163 U.S. at $552-53$ (Harlan, J., dissenting)

47. See C. LOFGREN, supra note 38 , at 28-60. 
in order to achieve improvements in service for blacks who were being mistreated on the existing integrated lines. ${ }^{48}$ Blacks who adopted this view, which was later to became Black Jurisprudence, were trapped in trying to alter the pohitical and economic rights available to black Americans within the framework that created legal apartheid and viewed the law only from a white perspective. The role of Black Legal Scholarship is to begin to unmask the prejudice in this "color neutrality" and deinand recognition of the black perspective-to define black Americans independently of white perspectives.

In 1954, the Supreme Court ruled that separate but equal was inherently unconstitutional with respect to public schools. The outcome in Brown required the right Supreme Court, the right issue, and the right time. It also required the re-education of the white judges who were subject to their own prejudices about black people. When Brown was decided, all the justices had been born in a century in which black people were slaves and inost (if not all) of the justices had not escaped froin the notion that black people were inferior beings. If the Court had been polled in 1954 on whether blacks and whites were equal im ability or had a right to real equality of opportunity, there would not have been a clear majority on the Court for either proposition. ${ }^{49}$ And when law professors such as Herbert Wechsler claimed that there was no neutral principle of constitutional adjudication with which to explain Brown, they were relying on a white perspective. ${ }^{50}$ From a white perspective, it is unclear what is wrong with separate but equal, but when one takes a black perspective,

48. Id. at 13 .

49. See R. KLUGER, supra note 27. I am not arguing that Brown was unimportant; it clearly helped to spur the efforts of civil rights activists, and it changed the legal environment substantially, even if not ininediately. See, e.g., Taylor Branch, Parting the Waters: America in the King Years, 1954-63 (1988) [hereinafter T. Branch, Parting the Waters]. But one could argue that even the inost liberal justices failed to live up to their own notions of equality and diversity. For example, Randall Kennedy argues that Justice Brennan hired his first black law clerk for the 1990-91 Term, but then retired from the Supreme Court and thus never actually einployed a black law clerk. See Randall Kennedy, Justice Brennan: Why No Black Law Clerks?, 3 RECoNSTRUCTION 51 (1991).

50. See Herbert Wechsler, Toward Neutral Principles of Constitutional Law, 73 HARV. L. REV. 1, 34 (1959) (claiming that there is no neutral principle which can justify Brown). Note how Wechsler casts this question in terins of a white perspective:

For me, assuming equal facilities, the question posed by state-enforced segregation is not one of discrimination at all. Its human and its constitutional dinnensions lie entirely elsewhere, in the denial by the state of frcedoin to associate, a denial that impinges in the same way on any groups or races that may be involved. I think, and I hope not without foundation, that the Southern white also pays heavily for segregation, not only in the sense of guilt that he must carry but also in the benefits he is demied. ...

But if the freedom of association is denied by segregation, integration forces an association upon those for whom it is unpleasant or repugnant.... Given a situation where the state must practically choose between denying the association to those individuals who wish it or imposing it on those who would avoid it, is there a basis in neutral principles for 
it is easy to see why Plessy was wrong and why Brown was constitutionally right. From this viewpoint, the aim of the whites who adopted segregation as a mode of social oppression is quite clear-blacks were oppressed precisely because the white majority believed that race mattered and that society slould give the white majority support for these claims. Black Jurisprudence understood this oppression, but it remained largely unexpressed in the arguments made to state and federal courts. Underlying the claim of Black Jurisprudence is a belief in a black perspective, but this claim is largely hidden behind color neutral arguments.

The claim of the proponents of a Black Jurisprudence tliat race matters is always couclied in neutral terms precisely because they otherwise would not be heard. When all that judges can hear is the clarion call of neutrality, any note of difference or exception falls on deaf ears. Thus, Black Legal Scliolarship had to wait for a different time and audience.

4. Being a Neutral Judge: An Example of the Limits of Black Jurisprudence. The experience of Judge U.W. Clemon provides an excellent illustration of the dilemma faced by black participants in the legal process in the world of Black Jurisprudence. Judge Clemon, a black lawyer appointed by President Carter to the federal district court bencli, had

holding that the Constitution deinands that the claims for association should prevail? ... I confess that I have not yet written the opinion.

Id. Wechsler cannot see the issue from the perspective of disenfranchised, powerless, and raciallysubordinated black people of the South, and-we were to learn-of the North. For a more thoughtful discussion that does ask how black people view this question, see Charles Black, The Lawfulness of the Segregation Decisions, 69 YALE L.J. 421,424 (1960). Black said,

Then does segregation offend against equality? Equality, like all general concepts, has marginal areas where philosophic difficulties are encountered. But if a whole race of people finds itself confined within a system which is set up and continued for the very purpose of keeping it in an inferior station, and if the question is then soleinnly propounded whether such a race is being treated "equally," I think we ought to exercise one of the sovereign prerogatives of philosophers - that of laughter. The only question remaining (after we get our laughter under control) is whether the segregation system answers to this description.

Here I must confess to a tendency to start laughing all over again. I was raised in the South, in a Texas city where the pattern of segregation was firmly fixed. I ain sure it never occurred to anyone, white or colored, to question its meaning. The fiction of "equality" is just about on a level with the fiction of "finding" in the action of trover. I think few candid southerners deny this. Northern people may be inisled by the entirely sincere protestations of many southerners that segregation is better for the Negroes, is not intended to hurt them. But I think a little probing would demonstrate that what is meant is that it is better for the Negroes to accept a position of inferiority, at least for the indefinite future. . . . Segregation in the South comes down in apostolic succession froin slavery and the Dred Scott case. The South fought to keep slavery, and lost. Then it tried the Black codes, and lost. Then it looked around for soinething else and found segregation.

Id. at 424. Professor Black does ask the Court to view the question of segregation froin the black perspective, but note how he uses the term "southerners" to refer to white southerners. In the end, for Professor Black and for the others who have written on this issue, the question is what did the "white" majority believe. By saying this, I am not questioning Professor Black's commitment to racial justice. He and Professor Wechsler are and were active participants in the struggle for equality for blacks in this country, but I would like to suggest that even the very best may sonietimes see the world through lenses that are distorted by the racial experiences they bring to the inquiry. 
been a state senator and civil rights activist. In a recent class action discrimination suit, United States v. Alabama, ${ }^{51}$ Judge Clemon ruled against the state of Alabama. He found that the Alabama schools were segregated by law and custom because of the continuance of a history of discrimination. Judge Clemon's opinion, far-reaching and extensive, included an order for Alabama to subinit a remedial plan. ${ }^{52}$ On motion by defendants, a stay was issued on February 14, 1986.53 Alabama, responding to this judicial command to remove discrimination with the alacrity that is its hallmark, ${ }^{54}$ successfully convinced the Eleventh $\mathrm{Cir}$ cuit Court of Appeals to vacate the decision made by Judge Clemon because of his refusal to recuse himself.

Like the other practitioners of Black Jurisprudence, Judge Clemon had been an active member of his community during the twenty years before his appointment to the bench. The Eleventh Circuit correctly noted that Judge Clemon need not recuse himself because he had children who could attend the Alabama schools and therefore would be affected by his ruhing, but the Court of Appeals concluded that Judge Clemon's participation in a small but related part of an anti-discrimination suit in Alabama several years earlier and his activities as a state senator in opposing the appoimtment of some of these parties to the Board of Trustees, violated the requirement that every effort be made to "guarantee to the defendant ... a totally fair and impartial tribunal . . . [free] from any himt or appearance of bias."ss

51. 623 F. Supp. 1137 (N.D. Ala. 1985), rev'd, 828 F.2d 1532 (11th Cir. 1987), cert. denied, 487 U.S. 1210 (1988).

52. Id. at 1173 .

53. United States v. Alabama, 828 F.2d. 1532, 1536 (11th Cir. 1987).

54. See United States v. Paradise, 480 U.S. 149 (1987). The Court noted that,

On February 10, 1984, less than two months from today, twelve years will have passed since this court condemned the racially discriminatory policies and practices of the Alabama Department of Public Safety. Nevertheless, the effects of these policies and practices remain pervasive and conspicuous at all ranks above the entry-level position. Of the 6 majors, there is still not one black. Of the 25 captains, there is still not one black. Of the 35 lieutenants, there is still not one black. Of the 65 sergeants, there is still not one black. Of the 66 corporals, only four are black. Thus, the department still operates an upper rank structure in which almost every trooper obtained his position through procedures that totally excluded black persons. Moreover, the department is still without acceptable procedures for advancement of black troopers into this structure, and it does not appear that any procedures will be in place within the near future. The preceding scenario is intolerable and must not continue. The time has now arrived for the department to take affirmative and substantial steps to open the upper ranks to black troopers.

Id. at 162-63 (quoting Paradise v. Prescott, 585 F. Supp. 72, 74 (M.D. Ala. 1983)).

55. 828 F.2d at 1539 (quoting United States v. Columbia Broadcasting Sys., 497 F.2d 107, 109

(5th Cir. 1974)). The Court went on to cite 28 U.S.C. $\$ 455$ (1942, as amended in 1974 and 1978):

[a]ny ... judge ... shall disqualify himself in any proceeding in which his impartiality might reasonably be questioned.

(b) He shall also disqualify himself in the following circumstances: 
From the perspective of colorblindness adopted by Black Jurisprudence, Judge Clemon should have recused himself. He had played a tangential role in proceedings that touched on the matter now before the court, an involvement that threatened to undermine the defendants' entitlement to a fair and impartial trial. There are many other judges without such a taint who could have provided the independence that was lacking in Judge Clemon. The problem with this perspective is that it adopts the white majority's view in Alabama. There are few black lawyers in Alabama who did not participate in the civil rights struggle-or at least none whoin blacks would like to see appointed to the federal bench. After all, Alabama has gone through one of the greatest political, social, and legal changes that has ever occurred with respect to race. A black lawyer with the skill to sit on the federal bench who did not participate in this struggle cannot bring the black perspective to the bench.

It is a special kind of paternalism that finds that Judge Clemon must recuse himself from this case for a white judge who also inust have participated in the struggle, most probably on the side opposite the interests of black people. Everyone in Alabama has been colored by the immensity of the changes that have taken place. However, under the perspective taken by the Eleventh Circuit, only black judges will be forced to recuse themselves. There is no white lawyer in Alabama who is old enough to sit on the Alabama district court and who did not have to confront the issue of race in his practice. The equivalent, froin the perspective of the white majority, would have been to exclude all former Confederates from ruling on black issues after the Civil War.

The Circuit panel understood that there was a problem, and it was troubled by the need to have black lawyers recuse themselves because of their blackness, but they were unable to see the problem as one of race. The per curiam decision noted,

To disqualify minority judges from major civil rights litigation solely because of their minority status is intolerable. This Court cannot and will not countenance such a result. The recusal statutes do not countenance such a double standard for minority judges. ${ }^{56}$

(1) Where he has a personal bias or prejudice concerning a party, or personal knowledge of disputed evidentiary facts concerning the proceeding;

(2) Where in private practice he served as lawyer in the matter in controversy, or a lawyer with whom he previously practiced law served during such association as a lawyer concerning the matter, or the judge or such lawyer has been a material witness concerning it;

(3) Where he has served in governmental employment and in such capacity participated as counsel, adviser or material witness concerning the proceeding or expressed an opinion concerning the merits of the particular case in controversy;

Id. at 1539 n.21 (einphasis added).

56. United States v. Alabama, 828 F.2d at 1542 (emphasis added). 
Unfortunately, they have accomphished exactly what they opposed by enforcing a "neutral" standard that is not neutral with respect to black judges. White judges who are known to be extremely insensitive to black concerns will contimue to preside in cases; only blacks will be removed by the court that read this rule in such a narrow manner. The Eleventh Circuit, therefore, has sanctioned the right of these white defendants to have a white judge decide their case. Black plaintiffs do not possess the same right to have black judges preside over their cases. Elemental fairness requires that whites not be able to accomphish imjustice in the name of neutral principles. The recusal statute as interpreted incorporates the right of white defendants to eliminate black judges in a wide variety of class action and class-based situations. Blacks have struggled too hard to alter the complexion of the bench for the resnlt to be that they can never judge cases involving racial discrimination.

In recusing himself in this case on reinand, Judge Clemon stated the problem clearly. He noted that Judge Vance, ${ }^{57}$ a former Chair of the Democratic Party of Alabama and the semor judge on the panel that ordered Judge Cleinon to recuse himself, had failed to recuse himself in a case involving crossover voting in the Deinocratic primary in Alabaina on the grounds that "it [is of] ... great importance that case assignment be made randomly, without influence or manipulation by any party or judge." $58 \mathrm{He}$ also noted that the United States v. Alabama per curiain opmion,

like the proverbial emperor, has no clothes. While I recognize the existence of the double standard, I am not resigned to it. The prudent course may well have been to stand mute in the face of the Knight opinion, but if I did so, the rocks would cry out.

Like every other judge, I have brought to the bench iny race, my background and my experiences. I view them as assets rather than

57. Judge Vance's tragic death is now attributed to Walter Leroy Moody, Jr., a self-employed literary agent. Mr. Moody's indictment contends that he killed Judge Vance and civil rights lawyer Robert Robinson because of concern about a suit pending before the district court in the Eleventh Circuit and because of racial bias. It is alleged that Moody was concemed about a school desegregation case that Judge Vance tried and the civil rights work of Robert Robinson.

In a strange twist of fate, Mr. Moody's first lawyer contended that all federal judges had to recuse themselves from this case because the indictment alleged that Moody was waging war on the federal judiciary. This motion has been withdrawn by subsequent counsel. In December of 1990, Mr. Moody was convicted by a federal jury of independent counts of bribery, obstruction of justice, and witness tampering in his 1972 federal bomb possession conviction. He is subject to up to 69 years in prison for those counts and up to six life terms for the counts associated with the most recent threats and bombs. See Jane Okrasinski, Who Tries a Colleagues Killer; Alleged Mail-Bomber Wants All Judges Recused, Legal Times, Nov. 26, 1990, at 10; Ronald J. Ostrow, Man Held In Mail-Bomb Murders, Los Angeles Times, Nov. 8, 1990, at 1, col. 2; Stephanie Saul, An Arrest in Fatal Mail-Bombs, NEwSDAY, Nov. 8, 1990, at 7.

58. Lee v. Macon County Bd. of Educ., 70-251-S, at 9 (N.D. Ala. 1988) (quoting Curry v. Baker, No. 86-7639 (11th Cir., Sept. 24, 1986) (Vance, J., mein.)). 
handicaps. I will not voluntarily remove myself, because of my race, from randomly assigned cases involving conflicts between black and white citizens, or traditionally black and traditionally white institutions of the State of Alabama. 59

My nonblack colleagues cannot understand Judge Clemon's argument. They simply do not see the difficulty associated with this concern. They do not see that Black Jurisprudence continues to require that black Americans conform to white perspectives.

In sum, the black arguments that led to the success in Brown and its progeny contain a kind of language spoken by black lawyers to white judges. It is a language, like other black dialects ${ }^{60}$ spoken to whites, that is different from the language spoken at home and understood at home by other blacks. It is a language that does not articulate many of the feelings that underlie the view of blacks in the legal process. If black participants in the legal process are to communicate fully the desires, fears, and concerns of the black community, then the law must move beyond the himited language of Black Jurisprudence. The law must begin to develop a dialect that looks beyond the narrowest, white-majority perspective of equality.

\section{Black Legal Scholarship and Feminist Scholarship}

The fact that the black struggle has produced a Black Jurisprudence but not, as yet, a Black Legal Scholarship, does not mean that the development of the former was a necessary precursor to the latter, or even that reform necessarily proceeds in that order. In fact, the effect of feminism on the law has taken precisely the opposite direction. Over the last ten years, a distinct Feminist Legal Scholarship has developed in American law schools, ${ }^{61}$ but the rise of this sophisticated alteruative vision of American law has to this point not nurtured an equivalent Feminist Jurisprudence. ${ }^{62}$ In this section, I explore the differences between these two legal phenomena and explain why the longer-hived Black Jurisprudence has not produced a distinct Black Legal Scholarship-until now.

It is not possible within the context of this Article to deal with all of the links between Black and Feminist Legal Scholarship, but I want to note the important differences that explain why women and not blacks have been successful in developing a perspective on legal scholarship.

59. Id.

60. See Joey Lee Dillard, Black English; Its History and Usage in the United STATES (1972).

61. See infra note 80 .

62. This does not of course mean that women judges have failed to have an impact on legal decisions. See infra note 77. 
There are three reasons for these differences in the development of distinctive legal scholarships and jurisprudence.

First, the experiences of black (male and female) and nonblack female lawyers have been quite different. Most black lawyers participated directly or indirectly in the organized legal struggle for black equality. ${ }^{63}$ This participation created results for black lawyers that produced a centralized vision of the law. Black lawyers had to persuade white judges of the correctness of their view of the Constitution-that blacks needed to be included in the community of rights that existed for white Americans. This left the participants of this struggle with a common way of approaching constitutional and legal questions that was radical, but not revolutionary. ${ }^{64}$ Participants implicitly adopted a legal perspective that ignored black interests: If white judges were to be convinced, they needed to be convinced from their own viewpoint that the legitimacy of their existing legal principles required inclusion of blacks. In other words, blacks were only demanding what whites claimed they believed in all along-equality under the law. ${ }^{65}$

Second, unlike the black struggle for civil rights, the search by women for justice was not primarily a product of court decisions. ${ }^{66}$ Women

63. Black lawyers were drawn into these controversies because they often went to law school to protect blacks from the vagaries of law and because the segregation of white law firms made their political and economic interests identical to that of the black communities of which they were a part. For the kinds of claims that were made on black lawyers, see $T$. BRANCH, PARTING THE WATERS, supra note 49.

64. See R. KLUGER, supra note 27, at 256-84 (1975) (describing NAACP Legal Defense Fund's effort to dismantle Jim Crow after World War 1I). As Randall Kennedy describes the demands by the Montgomery Bus Boycott, they seemed modest, but were radical in the context of the times and made a difference. Even these demands were not sufficiently radical to meet the standards of the NAACP, who wanted an all-out attack on segregation. Kennedy argues that

[i]t does make a difference-a huge difference-that largely because of reforms won by the

Movement, blacks are legally protected in the most significant domains against invidious

racial discrimination. . . The law created by the pressure of the Civil Rights Movement also speaks, has widely been heard, and is still very much alive.

R. Kennedy, Martin Luther King's Constitution, supra note 35, at 1062-63 (1989).

65. See R. BlAND, supra note 26, at 148-53 (1973) (discussing the political factors of the civil rights movement surrounding the appointment of Thurgood Marshall to the Supreme Court). For a fairly comprehensive list of appointed black judges, see ON BEING BLACK, supra note 23, at 166-82. The list of black lawyers who participated in various ways with the civil rights movement include but is not limited to the following: Robert Carter, Nathaniel Jones, Constance Baker Motley, Aubrey Robinson, Jr., U.W. Clemon, Jerome Farris, Cecil Poole, A. Leon Higginbotham, Spottswood W. Robinson, III, Theodore McMillian, Damon Keith, Joseph Hatchett. This does not mean that all black lawyers were so engaged or that they had a single perspective.

In addition, the results of the civil rights movement produced a black political force that wanted to ensure its continued protection by the courts and to vindicate its perspective of the law by seeking the appointment to the federal bench of black lawyer-participants in the civil rights movement.

66. This is not to say that court decisions played no part in the effort of women to win greater economic and social equality. Rather, my point is that court decisions were a by-product of a wider effort for such equality. The women's movement already had accomplished much by the time 
often have lost protection of their interests through court challenges by men, and the most important rights secured by women have been secured through the course of political action culminating in constitutional amendment ${ }^{67}$ and statutes, ${ }^{68}$ not through the successful reformation of the common law or constitutional interpretation. Feminist arguments frequently were not heeded by a judiciary that was largely composed of white males. When their arguments did command attention, it was often because men were seeking to limit the scope of legal protection for women in order to achieve some neutral equality for inen. ${ }^{69}$

The femimist equivalent to Brown v. Board of Education ${ }^{70}$ may be Roe v. Wade, ${ }^{71}$ which was decided almost twenty years after Brown. Brown secured for blacks a set of rights in this country that went far beyond the schoolhouse, and it helped to feed a growing protest inoveinent and struggle for equality that dated back to the abohitionist era. ${ }^{72}$ But Roe, on the other hand, was part of a more complicated struggle by

Brown v. Board of Education, 347 U.S. 483 (1954), was decided. The nineteenth amendment had given women the right to vote and the states had done very little in opposition to such a fundamental change in the status of women. Reed v. Reed, 404 U.S. 71 (1971), is the equal protection equivalent to Brown for woinen, but it did not have the same impact as did Brown because in 1971 there were fewer social impairments on white woinen both in employment and in terms of law compared to white men, than there were such impairments on the rights of black males compared to white males in 1954.

67. See U.S. ConsT. amend. XIX and the unratified equal rights amendment, H.R. J. Res. 1, 98th Cong., 1st Sess. (1983); S.J. Res. 10, 98th Cong., 1st Sess., reprinted in 129 CoNG. REC. 5529-30 (1983).

68. See The Equal Pay Act of 1963, 29 U.S.C. $\S 206$ (d) (1988) (prohibiting wage discrimination based on gender); Title VII of the 1964 Civil Rights Act, 42 U.S.C. $\$ 2000$ (1988) (making discrimination because of gender illegal except for bona fide occupational qualifications). However, note that the imclusion of sex was first proposed by an opponent of the Civil Rights Act of 1964 in order to demonstrate the ridiculous nature of the protections suggested for blacks. See Charles Whalen \& barbara Whalen, The Longest Debate: A legislative History of the 1964 Civil RIGHTS ACT 115-18 (1985).

69. See, e.g., Craig v. Boren, 429 U.S. 190 (1976) (Court invalidated a statute that permitted women to buy beer at 18 and men at 21 by extending to inales between 18 and 21 the right to drink beer); Weinberger v. Wiesenfeld, 420 U.S. 636 (1975) (unanimous Court invalidated provisions of the Social Security Act which provided social security survivor's benefits for widows but excluded widowers by extending the benefit only to iminor children); Frontiero v. Richardson, 411 U.S. 677 (1973) (Court struck down statute that required male spouses to prove they receive inore than $50 \%$ support from wife in order to obtain military benefits even though female spouses were automatically eligible). But see Stanton v. Stanton, 421 U.S. 7 (1975) (near-unanimous Court concluded that Utah statute that obligated parents to provide support for men to 21 and women to 18 was irrational and remanded issue of appropriate remedy to Utah state courts). See also supra note 66 (discussion of Reed $v$. Reed).

70. 347 U.S. 483 (1954).

71. 410 U.S. 113 (1973).

72. See Adam Fairclough, To Redeem the Soul of America: The Southern Christian Leadership Conference AND MARTIN LUTHER KING, JR. 21-22 (1987); Aldon MORRIS, The Origins of the Civil Rights Movement: Black Communities Organizing for Change 1-16 (1984). 
women for social justice. In short, Roe was not the watershed achievement and focal point of civil rights for women that Brown was for blacks.

Finally, blacks shaped part of the image of who they are in terms of how the law treated them. The courts often were ahead of the grassroots movements in terms of demanding access for blacks to public institutions. In contrast, woinen's efforts at creating a more gender-fair society have not been focused on how the law views woinen. ${ }^{73}$ Brown significantly altered blacks' understanding of where they were and where they could be in society and provided a bulwark for future struggles. Roe, on the other hand, did not provide the intellectual support for a feminist viewpoint that Brown provided for the civil rights agenda. Roe was, and still is, an important statement of feminist concerns, but feminist descriptions of theinselves were not as ineluctably intertwined with Roe as black deinands for equality were fused with the holding in Brown.

Even if Roe is recognized as an important exception to the general rule that there are very different legal experiences for blacks (inen and women) and nonblack women, it is clear that it is unique, or almost so, in the history of women and the law. For example, the adoption of the nineteenth amendment, which enfranchised women, did not produce the kind of recriminations that were associated with the adoption of the fifteenth amendinent, which accomplished the same for black men. There was no widespread attempt by the states to create a grandfather clause for woinen after the nineteenth amendinent was adopted, and there was very hittle litigation associated with its passage. ${ }^{74}$ Many of the statutory and constitutional successes of woinen simply were reaffirmations of the social trends and the existing fact of women's position in society. This lias not been true for the rights of blacks. The courts have played a significant role in the acquisition and removal of rights. Starting with Dred Scott v. Sandford, ${ }^{75}$ proceding through the Civil Rights Cases and Plessy v. Ferguson, and ending with Brown v. Board of Education and Regents of the University of California v. Bakke, ${ }^{76}$ black rights and judicial interpretation have been inseparably entwined.

73. The long push for the equal rights amendment is an important exception to this argument. See Mary Frances Berry, Why ERA faIled: Politics, WOMEN's Rights ANd the AMENDing Process of THe Constitution (1986); JANE MANSBRIDGe, Why We Lost THE ERA (1986).

74. The only situation analogous to the "grandfather clause" and other efforts at evading the fifteenth amendment were a number of cases involving whether the nineteenth amendment required women's service on juries. See, e.g., McDaniels v. Arizona, 62 Ariz. 339, 158 P.2d 151 (1945) (The nineteenth amendinent did not affeet the status of woinen with respect to juries because woinen already held the right to vote under the state constitution.). Woinen became eligible to serve on all federal juries only by virtue of the Civil Rights Act of 1957. See Sail'er Inn, Inc. v. Kirby, 5 Cal. 3d 1, 19 n.18, 485 P.2d 529, 540 n.18, 95 Cal. Rptr. 329, 340 n.18 (1971).

75. 60 U.S. (19 How.) 393 (1857).

76. 438 U.S. 265 (1978). 
During the last thirty years, women's rights have not been secured primarily as a product of arguments to the courts. Women's changing role and increased legal protection were primarily the product of political movements that altered the landscape and changed the statutes that provided the rules of the game. This meant that there was no successful feminist bar from which most female judges could be selected to serve on the federal bench, ${ }^{77}$ and although there were calls by women's groups for more women judges, the beneficiaries of this call were not limited to women who had actively participated in the political struggle for women's equality. ${ }^{78}$ The women appoimted to the federal bench came from diverse

77. There are several obvious exceptions. Ruth Bader Ginsburg, for example, who litigated Reed v. Reed, 404 U.S. 71 (1971), now sits on the D.C. Circuit. Several other women judges have also participated in the struggle for sexual equality, but this fight did not dommate the efforts of members of the female bar in the 1960s and 1970s as it did the black bar in the 1950s and 1960s. Even the black Republican equivalent of Sandra Day O'Connor, Jewell LaFontant, was a woman who played a role in the civil rights struggle. Black women lawyers-for example, Constance Baker Motley-were leaders in the struggle for racial justice, not for feminism. There were few prominent black lawyers of either sex or party who were nonparticipants in the struggle for racial equality. Karen Morello notes that the first women on the bench in the 1880 s were suffragists, but most, like Florence Allen (the first woinen on the Court of Appeals) were lawyers who happened to be women. This fact shaped soine of their views, but they did not seek to create as completely an alternative vision of society. See Karen Morello, The INvisible BAR: The WoMEn IN AMERICA, 1638 To THE PRESENT 218-47 (1986) (describing the exclusion of women from the judiciary). Women judges have a feminist consciousness, i.e., they know they are women, but they have not developed a separate feminist judicial perspective of the law, i.e., a Femimist Jurisprudence.

78. The appointment of Sandra Day O'Connor is a good example of this difference. Although Justice O'Connor had been involved in soine political efforts and had supported the equal rights amendment as a state legislator, she had not been engaged in a concerted effort as a lawyer for equal justice. Justice O'Connor has staked out some views that are different from the perspective of the male inembers of the Supreme Court. For instance, her concurrence in Johnson v. Transportation Agency, 480 U.S. 616, 647 (1987) (O'Connor, J., concurring), is very different from Justice Scalia's dissent, which concludes that affirmative action for woinen and ininorities discriminates against white men like his father who were immigrants to this country and who did not participate in any racial discrimination. Id. at 657 (Scalia, J., dissenting).

One has to read the statement of Justice Scalia in light of the statements of Professor Scalia. Scalia made the following arguinent based on his own ancestry:

My father came to this country when he was a teenager. Not only had he never profited froin the sweat of any black inan's brow, I don't think he had ever seen a black man. There are, of course, many white ethnic groups that came to this country in great numbers relatively late in its history-Italians, Jews, Irish, Poles-who not only took no part in, and derived no profit from, the major historic suppression of the currently acknowledged minority groups, but were, in fact, theinselves the objeet of discrimination by the dominant Anglo-Saxon majority.... Yet curiously enough, we find that in the system of restorative justice established by the [John Minor] Wisdoms and the [Lewis F.] Powells and the [Byron R.] Whites [Anglo-Saxon white judges], it is precisely these groups that do most of the restoring. It is they who, to a disproportionate degree, are the competitors with the urban blacks and Hispanics for jobs, housing, education-all those things that enable one to scramble to the top of the social heap where one can speak eloquently (and quite safely) of restorative justice.

...

... I am entirely in favor of according the poor inner-city child, who happens to be black, advantages and preferences not given to iny own children because they don't need them. But I am not willing to prefer the son of a prosperous and well-educated black 
backgrounds, and the feminist jurisprudential vision that animates their activity as judges is more diffuse than for black Americans. ${ }^{79}$ Feminist Legal Scholarship was not limited by a fidelity to a preexisting set of legal assuinptions upon which the movement had been based. The lack of these assumptions permitted feminist legal thinkers to stake out views that reject the doininant male perspective without first having to free themselves of the restraints of a Feminist Jurisprudence. ${ }^{80}$

\section{ORIGINAL UNDERSTANDING OF RACE AND THE LAW}

\section{A. Black Legal Scholarship and the Founders and Framers of the Constitution}

One way of defining Black Legal Scholarship is to contrast it with the doinmant legal scholarship about black Americans and the Constitution, which leaves black perspectives and experiences out of the law. The Framers were the first contributors to this view of blacks and the law. When the original draft of the Declaration of Independence included a condemnation of King George for forcing the slave trade on the colonies, it was removed because it was too controversial. ${ }^{81}$ Similarly, the Framers did not mention slavery explicitly in any provision of the Constitution or the Bill of Rights, which was passed shortly thereafter. Indeed, only the passage of the thirteenth amendinent ensured that future generations of school children would even be taught that slavery existed. Without such a constitutional reference, one can imagine some future editors of history texts leaving out that sonewhat difficult history. Most Americans believe that because race is not mentioned, it cannot be a pivotal issue. In law as in life, however, the unexplained and often unexplored assumptions-the axioins that form the core of one's doctrine-often are more important than the nained constraints. A New York legislator put

doctor or lawyer-solely because of his race-to the son of a recent refugee from Eastern

Europe who is working as a manual laborer to get his family ahead. . . .

Antonin Scalia, The Disease as Cure, 1979 WASH. U.L.Q. 147, 152-54.

79. See K. MORELLO, supra note 77, at 218-47.

80. See Catharine MacKinnon, Feminism Unmodified: Discourses on Life and LAW (1987); Ann Scales, The Emergence of Feminist Jurisprudence: An Essay, 95 YALE L.J. 1373 (1986); Nadine Taub \& Wendy Williams, Will Equality Require More than Assimilation, Accommodation or Separation from the Existing Social Structure?, 37 RUTGERS L. REV. 825 (1985); Note, Toward a Redefinition of Sexual Equality, 95 HARv. L. REv. 487 (1981). One should note that some of this literature uses race cases to make its point about sexism. See, e.g., C. MACKInNon, supra, at 63-69 (drawing parallels between the treatment of women and Native Americans in a predominantly white male culture). It may be that being permitted to see law without the limitation of a prior jurisprudence will limit the feminist movement as much or more as the existence of a prior jurisprudence has limited black legal scholarship.

81. See John Chester Miller, The Wolf By the Ears: Thomas Jefferson and SlavERY 1-11 (1977). 
it best in the discussion about the proposed wording of the new New York Constitution in 1832. He said that if slavery was never mentioned in the new constitution, then future generations would forget that slavery had ever existed in New York. ${ }^{82}$ Similarly, many constitutional scholars have failed to include the black perspective in their views of constitutional interpretation. This tiberal view of the Constitution and race, that race is better left unexplored, prevailed im inuch of the constitutional drafting. Even the drafting of the great Civil War amendments-the thirteenth, fourteenth and fifteenth amendments-conceived in the shadow of the great American war and stained with the blood of constitutional absolutisin, suffers froin this hiberal bias agamst the explicit inclusion of blacks in the constitutional structure. ${ }^{83}$

The original Constitution refers indirectly to blacks in four places; 84 yet race and slavery, although never explicitly mentioned, cemented the

82. Arthur Zilversmit, The First Emancipation: The Abolition of Slayery iN THE NORTH vii (1967).

83. The first legislation that blacks had some official role in creating was the Civil Rights Act of 1875. See John Hope Franklin, Martin Luther King. Jr. And the Afro-American Protest Tradition, in We Shall Overcome 106-07 (Peter J. Albert \& Ronald Hoffman eds. 1990).

84. The first clause of the U.S. Constitution in which slavery is indirectly implicated is article 1 , $\S 2, \mathrm{cl} .3$, which provides that representation shall be based upon the "whole number of free persons, including those bound to Service for a Term of Years, and excluding Indians not taxed, three fifths of all other Persons." Id. (emphasis added). The phrase "all other persons," of course, refers to black slaves. This clause did not exclude from the census indentured servants, i.e., those bound to servicc for a term of years, nor (though it is not clear from the passage) were women and children excluded from the census and representation. Even Indians, who were taxed and accordingly were a part of the general populace, were included in the census. Excluded from representation were untaxed Indians and two fifths of "other persons." This coinpromise, borrowed froin the Articles of Confederation, consciously decided to treat slaves differently and to do so in a color neutral manner.

The other three veiled references to slavery are article IV, $\S 2, \mathrm{cl} .3$ and article I, $\S 9$, cl. 1, and article V. Article IV provides,

No Person held to Service or Labour in one State, under the laws thereof, escaping into another, shall, in Consequence of any Law or Regulation therein, be discharged from such Service or Labour, but shall be delivered up on Clain of the Party to whom such Service or Labour inay be due.

Id. art. IV. Article $\mathrm{V}$ provides for the process of amending the Constitution with two limitations: that "no Amendinent which may be made prior to the Year One thousand eight hundred and eight shall in any Manner affeet the first and fourth Clauses in the Ninth Section of the first Article; and that no State, without its Consent, shall be deprived of its equal Suffrage in the Senate." Id. art. V. Article I, $\S 9$, cl. 1 provides,

The Migration or Importation of Such Persons as any of the States now existing shall think proper to admit, shall not be prohibited by the Congress prior to the year one thousand eight hundred and eight, but a Tax or duty may be imposed on such Importation, not exceeding ten dollars for each Person.

Id. article $\mathrm{I}, \S 9$, cl. 1. When read together, these four sections prevent the Congress froin doing anything, including amending the Constitution, to prevent the importation of black slaves before 1808 , and they require those states that become sanctuaries for escaped slaves to return them to their masters. In addition, by preventing the reduction in the number of Senators without a state's approval, the Constitution insured that there would not be a change in power in the Senate without the approval of those slave states which made up approxinately half of the states in the new country. 
Great Compromise between the Southern slave-holding states and the Northern states together like a bloody glue. ${ }^{85}$

The most important example of the tendency to remove the black experience and perspective from the law is found in the arguments of those who advocate a return to original intent. To rely on original intent is to hitch our interpretational scheme to a vision that excluded blacks. Justice Thurgood Marshall made this point recently by giving a black perspective on the original flawed nature of the Constitution. He noted in his remarks that there really were two Constitutions. The first provided limited rights for large seginents of the population. Justice Marshall contended, however, that a second Constitution evolved through the Civil War amendments and altered the constitutional framework so that substantive rights were provided to black Americans and women. Justice Marshall argued that this second Constitution, the post-Civil War Constitution, ought to be considered the more important document. ${ }^{86}$

Justice Marshall's comments provoked a firestorm of criticism. Some conservatives contended that these remarks reflect an attitude that is inappropriate for a justice on the Supreme Court, and they called for his resignation. ${ }^{87}$ Liberals also criticized Justice Marshall. Professor Laurence Tribe of Harvard concluded that Marshall's view that the original Constitution was flawed took the wrong approach to constitutional

William Wiecek has listed eight provisions of the Constitution that directly implicated slavery. For example, Wiecek argued that the provisions invoking the federal power to suppress insurrections and to protect states against doinestic violence were largely directed toward prohibiting slavery. See WILLIAM WIECEK, SOURCES OF ANTISLAVERY CONSTITUTIONALISM, 1760-1848, at $62-80$ (1977). I have not included these sections in this discussion because from this perspective-a perspective I largely share-the entire Constitution was a reaction to slavery. The institution of slavery required a inore powerful central government as well as a government controlled by the states that were dependent on slavery.

85. See, e.g., MaX Farrand, The Framing of the Constitution of the United States 91-112 (1913) (discussing the development of the Great Compromise). But see William Wiecek, The Witch at the Christening: Slavery and the Constitution's Origins, in The FRAMING AND RATIFICATION OF THE CONSTITUTION 167, 178-81 (Leonard W. Levy \& Dennis J. Mahoney eds. 1987) (Slavery was at the heart of the Great Comproinise between the Southern slave-holding states and the Northem states.).

86. Thurgood Marshall, The Constitution: A Living Document, 30 How. L.J. 915 (1987).

87. For an example of this attitude, see Tony Mauro, Washington Legal Foundation Marks 10 Conservative Years, MANHATTAN LAwYER, December 8, 1987, at 13. Mauro argued,

Justice Thurgood Marshall failed to heed the WLF's (Washington Legal Foundation) call to resign because of his critical stance on the bicentennial celebration for the U.S. Constitution. "I hate the double standard," [Dan] Popeo [Legal counsel for WLF] said. "You've got all these people running around worrying about Robert Bork's vision of America, and here you have Thurgood Marshall on the sunny shores of Hawaii asking, Why celebrate the Bicentennial? He clearly holds a bias, a prejudice that makes hiln unfit to serve."

Id. See also Ted Gest, Blasts Bicentennial of Constitution; Justice Marshall's minority report, U.S. NEws \& WORLD REP., May 18, 1987, at 12. 
interpretation. ${ }^{88}$ However, Marshall's view-the quintessential Black Jurisprudence-does not go far enough. He notes that blacks were not involved as participants in the original intent, but he is unwilling to demand black participation in constitutional formation. It is a persistent myth held by constitutional experts that the political wisdom that existed in 1787 and 1868 created a kind of Athenian citizenship that-although originally imperfect in its exclusion of blacks, wonien, and the poor-was eventually extended by constitutional amendnient and statute to include all Americans. This view seems fundamentally flawed. It argues that only the views and perspectives of the white participants in the creation of the Constitution should be heard.

There are four, often unstated, justifications for the original intent approach. First, it is possible to argue that the process that was created was good and that the political wisdon inherent in the Great Conipromise of 1787 and in the creation of the thirteenth, fourteenth, and fifteenth amendments after the Civil War created a utopian notion of legal rights and citizenship. ${ }^{89}$ This argument is not persuasive because this

88. See Laurence Tribe, Roots and Limits of Judicial Review, in Constitutional Roots, RighTS, AND RESPONSIBILITIES 23-24 (1987).

89. The writings of John McCord are typical of the group of scholars that puts forth this view. Professor McCord opines:

The Civil Rights Movement was announced at Philadelphia on July 4, 1776. A group of self-styled representatives of a people which enjoyed unequal station declared that they were free and "that all men are created equal, that they are endowed by their Creator with certain inalienable Rights, that among these are Life, Liberty and the pursuit of Happiness." After freedom was won, an organic civil rights act, the Bill of Rights, was a first order of business.

Nearly a century later, a constituent people, accidentally black, also were declared to be free and the organic law of civil rights was extended to this constituent minority.... [W]e think it important initially to note that freedom and human aspiration, govermment and civil rights, and the integrity of society and of its legal institutions do not comprehend essentially different things when considered in the context of different classes of people. $A l l$ civil rights movements are one in principle and one in realization. The distortion of a principle or the denial of aspiration affects all society, not merely the individual or class deprived. In this light, the Negro Civil Rights Movement is not unique; it is a contemporary expression of the Civil Rights Movement of 1776.

With All Deliberate Speed, at V (John McCord ed. 1969) (emphases added). This argument seems silly in light of the history of the Constitution's adoption and the background of racism that informs that history. In addition, it is odd to suggest that a Bill of Rights was the first order of business for the new nation when it was not included in the constitution which was adopted substantially after the Revolutionary War was won at Yorktown in 1784. However, at the very heart of this view is the argument, often unstated, that the condition of black Americans was an accident unconnected to the color of their skins. If the race of black Americans is not important in determining the status of black Americans it is hard to think of what is important. Racism is not an accident; it was and is intentional. See, e.g., Chief Justice Taney's decision in Dred Scot v. Sandford, 60 U.S. (19 How.) 393, 451 (1856) (stating that the Constitution makes no distinction between the property of the master in a slave and any other property).

The view that the American Constitution has this special niehe in history is not limited to law professors. Alan Bloom dismissed the early history of race and racism in the Constitution. Bloom labels the Constitution as the finest political gift that Western Civilization has given the world. He 
vision of "Athenian citizenship" has not created social or economic equality for black Americans. The success of this notion of American citizenship for other politically dispossessed groups of 1787 does not mean that it can or should be expected to work for black Americans. ${ }^{90}$

Second, it can be argued that it is not possible to infer what black people would have successfully argued about the Constitution and what concessions would have been won. Who would represent the blacks of 1787-the blacks who were free, or some illusory black aristocracy, similar to the group of white Americans who represented white America and created the constitutional principles?

This argument also is flawed. Although it is difficult to discern how black Americans would have impacted the Constitution, it is no more difficult than deterinining the assumptions that underlie the original intent of the Framers' writings. After all, what we now view as the most important notes of the constitutional convention were not available for the first fifty years of constitutional litigation. ${ }^{91}$ In fact, a useful question not clearly answered by the available evidence is whether the Framers intended that their ideas that were unexpressed in the Constitution should shape our understanding of the constitutional process.

It is particularly odd to exclude the perspectives of blacks on the Constitution when the views of those who opposed the adoption of the

understands that for blacks to demand a place in the creation of constitutional values is a demand for power that his view of the Constitution cannot countenance. See Allan Bloom, The Closing of THE AMERICAN MiND 33-34 (1987). For the reasons he is wrong, see infra notes 52-64 and accompanying text. George Anastaplo writes:

Various of the amendments make explicit, or confirm, what had been taken for granted or at least had been aimed at from the outset. Even the Civil War amendments - the Thirteenth, Fourteenth, and Fifteenth Amendments-are consistent with, if not called for by, the American constitutional spirit.

George Anastaplo, The Constitution of 1787, at 11 (1989). See also Walter Dellinger, 1787: The Constitution and "The Curse of Heaven": A Commentary, 29 WM. \& MARY L. REv. 145 (1987). Dellinger argues that "both slavery and race have had an enormous impact on the development of the American Constitution, and we cannot fully understand our present constitutional conflicts over the permissible use of race unless we understand the role of race in our constitutional origins and throughout constitutional history." Id. at 152.

90. The extent to which this actually has happened for the poor, except for the poor whites of Appalachia, is outside the scope of this Article. The few who have examined the question normally have asked the question about today's poor who, although descended from poor whites, are not a permanent class of poor people. Except for black Americans, there has been no class of serfs. See L. HARTZ, supra note 30 .

91. James Madison's Notes of Debates IN THE FEDERAL Constrtution of 1787, stands as "the standard authority for the proceedings of the Convention," despite being unavailable until fifty years after the convention." Adrienne Koch, Introduction, xxiii, in JAMES MADISON, Notes of DEBATES IN THE FEDERAL CONSTrTution of 1787 at xxiii (1966). But see Robert Bork, The TEMPTING OF AMERICA 144 (1990) ("The common objection to the philosophy of original understanding-that Madison kept his notes of the convention at Philadelphia secret for many years-is off the mark. He knew that what mattered was public understanding, not subjective intentions."). 
Constitution at the Convention and who did not sign it are consulted and included by those who would discern "original" intent.92 When we include the views of such "Framers" in our interpretation and exclude black participation, we give a preference to those "Framers" " views that can only be due to skin color.

Those who hold the dominant view that blacks have nothing to add to original intent also make the assumption that there were no common themes that could be the basis of a "black" perspective on the Constitution. In the process of posing, in constitutional terms, the unthinkable question of the place of the black experience in constitutional thought, we create a need to consider how black Framers would have reshaped the Constitution in ways that are sensitive to the black experience. More evidence than we acknowledge is available for this task. ${ }^{93}$

Third, it can be argued that blacks had nothing to add to the process of defining American citizenship. What could black Americans provide that Thoinas Jefferson did not include in the Declaration of Independence or that Benjamin Franklin and James Madison did not add to the Constitution? ${ }^{94}$ This contention makes the fundamentally ethnocentric assumption that black perspectives on legal questions do not matter because there are no real differences between the perspectives of blacks and whites. Under this view, slavery was an aberration whose effects were erased by the passage of the Reconstruction Amendments. And after the passage of these amendinents, the Court could hold that law had done enough to save black Americans and their interests. Writing for an eight-man majority in the Civil Rights Cases, Justice Bradley took this view:

When a man has emerged from slavery, and by the aid of beneficent legislation has shaken off the inseparable concomitants of that state, there must be some stage in the progress of his elevation when he takes the rank of mere citizen, and ceases to be the special favorite of the laws, and when his rights as a citizen, or a man, are to be protected in the ordinary modes by which other men's rights are protected. ${ }^{95}$

From this perspective, the black experience becomes irrelevant to the process of defining rights. When Congress passed the Civil Rights Act of 1964 to limit the power of the states to mandate segregation, Con-

92. See H. Jefferson Powell, The Original Understanding of Original Intent, 98 HaRv. L. REV. 885 (1985). For example, Edmund Randolph, George Mason, and Elbridge Gerry were all present at the Philadelphia Convention, but refused to sign the final draft of the Constitution. In spite of their refusal, their views are taken into account by those who seek the original intent of the Framers.

93. For example, Professor Waldo Martin discussed the views of Frederick Douglass on the Civil War Amendments and the role of race and slavery in the Constitution in WALDO MARTIN, JR., THE MiNd of Frederick Douglass 136-64 (1984).

94. See Bell, Foreword, supra note 25, at 4-5.

95. I09 U.S. 3, 25 (1883). 
gress chose not to rely on the amendments that are supposed to remedy the effects of slavery. Instead, Congress primarily relied on the Commerce Clause. ${ }^{96}$ Given the option of examining the continued racism through the lens of the thirteenth, fourteenth, and fifteenth amendments, the Congress and the courts chose to use other ineans. ${ }^{97}$ This approach means that justice is still defined in terms that derive froin the perspectives of white citizens. Black interests in this question have been, and still are, ignored. ${ }^{98}$ The real reason that black perspectives are excluded from this discussion is that most white scholars and white people believe it is inproper for blacks to raise or make such claims on the Constitution or judicial interpretation.

The final unstated rationale for excluding black perspectives from the definition of original intent is that the citizens who created the Constitution in 1787 created a contract that all citizens join implicitly in accepting citizenship in the United States. This contract was extended and made even inore appropriate by the extension of the right to vote to blacks and to women by the fifteenth and the nimeteenth amendments. ${ }^{99}$ Presumably blacks, if they did not like this contract, could have left the Ainerican republic. There were substantial efforts before, ${ }^{100}$ during, ${ }^{101}$ and after ${ }^{102}$ the Civil War to extract blacks from the United States by "repatriating" thein to Africa or by sending blacks to the Caribbean or Brazil. In addition, some black leaders opposed colonization - the forced

96. See DerRick Bell, RACE, RaCiSm ANd American LAw 96-101 (2d ed. 1980). See also Heart of Atlanta Motel, Inc. v. United States, 379 U.S. 241 (1964) (holding that the commerce power was adequate grounds for congressional civil rights action).

97. This ignores the important fact that the legislatures and the Congress that passed and ratified these amendments were essentially all white. Black concerns were only partially heard by these "representative" bodies.

98. For a more comprehensive attempt to address this question, see Randall Kennedy, Equality as a Constitutional Concept, 47 MD. L. REv. 46 (1987); Randall Kennedy, Afro-American Faith in the Civil Religion; or Yes, I Would Sign the Constitution, 29 WM. \& MARY L. REv. 163 (1987).

99. See supra note 89 .

100. See, e.g., Louis Filler, Crusade Against Slavery: Friends, Foes, ANd Reforms, 1820-1860, at 26, 32, 38, 115, 252 (1986); George Fredrickson, The Black IMAGE IN THE White Mind: The Debate on Afro-American Character and Destiny, 1817-1914, at 113118 (1972). These efforts included several antislavery novels that argued that the resolution was emigration. See Elizabeth Roe, Aunt Leanna: On Early Scenes in Kentucky (1855); HarRIET BeEcher Stowe, UnCle Tom's Cabin (1852). See generally Lorenzo TuRner, ANT1Slavery Sentiment in American Literature Prior to 1865 (1929).

101. See Douglass, What Shall Be Done With the Freed Slaves?, in 3 The LIFE AND Writing OF Frederick Douglass, supra note 34, at 297-99; ChARLES Strozier, LiNCOLn's QUeST FOR Union: Public and Private Meanings 175-77 (1982).

102. Emma Thornbrough, T. Thomas Fortune, Militant Journalist $70-75$ (1972). There were also always movements among blacks for voluntary returns to Africa, including calls by Paul Cuffe, Martin Delaney, and Bishop Henry McNeal Turner for emigration to Africa. The most famous effort, of course, is that of Marcus Garvey. See John Clarke, Marcus Garvey AND tHE VISION OF AFRICA (1974). 
repatriation of black Americans-but argued that blacks should consider emigration to South or Central America. ${ }^{103}$ All of these efforts failed because Congress was unwilling to provide the wherewithal to transport blacks to some other place, because of the hostility of those other places to the specter of thousands of American blacks being transported into their midst, ${ }^{104}$ and because black Americans claimed that they in fact were Americans and could not be forced to emigrate. ${ }^{105}$

The other members of the American polity either are descendants of those who helped create the American Constitution, or they or their ancestors voluntarily came to America as immigrants who, it may be argued, accepted the constitutional contract when they embarked on boats and planes to come here. It is true that many immigrants faced dire economic straits or were under other constraints that led them to come to America, but those problems, particularly in the 19th and early 20th century, were not the result of actions by the United States. Most immigrants came to the Umited States, at least partly, because of the rules produced by the Constitution-not in spite of them.

Contract analysis requires some consent that is voluntarily produced and freely joined by the people. Yet black Americans never experienced such a choice with respect to the American Constitution. They were not active participants either in Philadelphia in 1787 or in Washington in the 1860 s when the constitutional framework was created. The vast majority of black Americans were not voluntary immigrants to the United States and, therefore, did not consent to the "constitutional contract." If courts attempt to use the contract notion to justify the imposition of the constitution, more support is required for inferring a voluntary acceptance of this Constitution by blacks.

All four of these contentions grow out of an originalist perspective of the Constitution. Most constitutional scholars would reject the notion

103. Among those leaders was Henry H. Garnet. See Stirling Stuckey, Slave Culture 180-88 (1987). Indeed, although most black leaders vehemently opposed the colonization efforts of whites in the antebellum period, they were of two minds about how blacks ought to view themselves. So, for example, Frederick Douglass, one of the great integrationist and one who eventually argued that the Constitution was an antislavery document, could say, in opposition to charges that he was not attached to this country, "I have no love for America, as such; I have no patriotism; I have no country. What country have $I$ ? The institutions of this country do not know me, do not recognize me as a man." Frederick Douglass, National Anti-Slavery Standard, May 20, 1847, reprinted in 5 THE LIFE AND WRITINGS OF FREDERICK DOUGLASS, supra note 34, at 522 n.59. Garnet, the noted nationalist, responded that blacks had rights in America. See S. STUCKEY, supra, at 175.

104. WINTHROP JORDAN, WhITE OVER BLACK 549-62 (1968); Warren A. Beck, Lincoln and Negro Colonization in Central America, 6 ABRAHAM LINCOLN QUARTERLy 162 (1950).

105. See Frederick Douglass, Speech at American Anti-Slavery Society (May 1848), reprinted in 5 The LIFE AND WRITINGS OF FREDERICK Douglass, supra note 34, at 78-85. 
of originalism. 106 Even some of those scholars whio would not completely reject originalism contend that the document as written has no meaning. They would argue that the most important factor in thinking about the Constitution las to do with understanding and creating present interpretations of constitutional principles. ${ }^{107}$ The past is considered irrelevant to much of that interpretation unless it directly tells the present interpreters low to view the Constitution witl respect to our present problems. This view of the history is much too narrow: It fundamentally-although very much in the tradition of American experience-ignores the importance of original understandings to thinking about the Constitution and the development of American law.

Almost all notions of originalism are subject to the criticism that they ask black concerns to defer to white concerns. Blacks were not consulted by the "Founders" nor were their concerns considered relevant by the drafters. Jefferson wrote the Declaration of Independence and Madison wrote the preliminary draft of the Constitution-Frederick Douglass did not. Black people cannot enter the dispute about low to define essential terins because they were not present. "Defer to the past" is the implicit message. Listen to the wiser and greater (and whiter) founders.

Justice Powell's opinion in the Bakke case is just such a call for the deference of black Americans to white concerns. ${ }^{108}$ Powell concluded that the University of Califorina, a state institution, sliould be able to give preference in adinission to the sons and daughters of its formerly allwhite alumni and to the sons and daughters of the essentially all-white political elite, but that it does not liave an equal interest in increasing the number of blacks in medicine in a state that liad never graduated a black doctor froin a state medical scliool. ${ }^{109}$ The ouly explanation offered by Justice Powell and the nrajority of those who have spoken on the issue is

106. This is true even of conservative and law and economics scholars. See, e.g., RichaRd PosNer, THE Problems OF JURISPRudenCe 293-99 (1990) (noting that by looking for answers in constitutional and statutory texts, "originalists" tend to ignore one of the key tenets of traditional legal reasoning-precedent that interprets those texts); Richard Posner, Bork and Beethoven, 42 STAN. L. REV. 1365, 1373-80 (1990) (plain meaning and originalism are difficult concepts to achieve for judges and should not be adopted by federal judges in the sense that Judge Bork suggests).

107. See, e.g., Michael J. Perry, The Constitution, the Courts, and Human Rights 91-145 (1982) (Perry argues for noninterpretist ways of thinking about the Constitution and asserts that the key function of noninterpretive review is the enforcement by the court of values not constitutionalized by the Framers.); John Hart Ely, Foreword: On Discovering Fundamental Values, 92 HARV. L. REV. 5, 15 (1978) (arguing that an important part of the Court's jurisprudence involves weighing the merits of certain policy or ethical judgments against certain fundamental values).

108. See Regents of the Univ. of Cal. v. Bakke, 438 U.S. 265 (1978).

109. Id. at $310-11$. 
that it is perfectly acceptable to require black interests to defer to white interests.

White interests are "first," "original," "produced by the founders," 110 or in some other manner take precedence over the rights of black people in this country. In adopting this approach, the Court clearly has not escaped the deference to the past that has governed relations between blacks and whites since blacks were wrenched from the coast of Africa.

When we ignore the history of racism in America; we fail to understand the history and present configuration of the American legal system. To take just one example, there was a very strong tradition in the English common law that innkeepers and others who had monopoly power over resources or who operated public accommodations were required to open them to the public unless the person seeking access was somehow disqualified. ${ }^{111}$ This tradition was carried into the American legal system, but the current rule is just the opposite: Anyone can be excluded-including exclusion for reasons of racial animus-unless exclusion violates an explicit civil rights statute. 112 As one New Jersey court noted, "[t]he denial of freedom of reasonable access in some states following passage of the Fourteenth Amendment, and the creation of a common law freedom to arbitrarily exclude following invalidation of segregation statutes, suggest that the current majority rule may have had less than dignified origins." 113

Unfortunately, little has been written about how this change occurred or why. Charles Haar and Daniel Fessler have examined the ancient doctrine of the duty of public carriers in a Southeru discriminatory context and have ignored the racial aspect of how the duty of innkeepers and others evolved because of the post-Civil War racism. ${ }^{114}$ They take

110. See Edwin Meese, Interpreting the Constitution, INTERPRETING THE CONSTITUTION: THE Debates OVer ORIGINAL INTENT 13 (Jack Rakove ed. 1990). For the most forceful support for originalism, see R. BORK, THE TEMPTING OF AMERICA, supra note 91, at 139-78. For a discussion of the almost religious view of the founders toward the Constitution, see MiCHAEL KAMMEN, $A$ MACHINE THAT WOULD Go OF ITSELF (1986).

111. See, e.g., Uston v. Resorts Int'l Hotel, Inc., 89 N.J. 163, 170-74, 445 A.2d 370, 373-75 (1982) (discussing common law tradition that those who operated public accommodations could not exclude people arbitrarily and unreasonably).

112. Id. at 171,445 A.2d at 374 .

113. Id. at 171 n.4, 445 A.2d at 374 n.4.

114. See Charles HaAr \& Daniel Fessler, Fairness and Justice (1986) (legacy of the Civil War and the changes produced by post-reconstruction jurisprudence is ignored). I fear black legal scholars who have begun to look at this question have fared no better. See LeMarquis DeJarmon, Public Accommodations, in WITH ALl Deliberate SPEED, supra note 89, at 85, 87 (discussing innkeepers and common carriers without reference to post-Civil War racism and its impact on access to public accommodations). 
the racial present as a given and do not question how or why we came to this position.

Similarly, property law owes much to the existence of slavery, and the notion of human property has shaped American law. Yet, the two most innovative thinkers on property-one a disciple of conservative individualism and the other the leading liberal theoretician-looked at the issue of property and takings and did not ask what limits the American history of slavery has placed on our thinking about property. ${ }^{115}$ Perhaps this is a result of the inadequacies in the legal education of this generation's scholars. ${ }^{116}$ Whatever the source of the incomplete understanding of the relationship between property and slavery, the essential point is that, without such an understanding, a considerable amount of history lacks explanation.

Legal scholars have virtually ignored the issue of race in thinking about what is important in the formulation of legal theory. However, we cannot understand the potential power of the law unless we understand how law has strained and contorted itself under the constraints imposed by the history of racism in American law. In an age when it is at least a social misdemeanor-if not a full-fledged social felony-to accuse anyone of racism, it is time for legal scholars to see, understand, and deal with the racism of our legal history. Those who deny that they are bound by original understandings must accordingly deal with the lessons of two hundred years of these understandings.

\section{B. Four Ways of Looking at Race and the Law}

There are four ways to construct the basic relationships between race and the law that have dominated the legal experience of black Americans. The pattern of laws is not exactly the same for any state or

115. Bruce Ackerman does not mention slavery or race at all. Even though his is a policy book and not a history book, it is likely that thinking about how race would impact on the notion of property and takings would have enlarged and possibly ennobled the book. See BRUCE A. ACKERMan, Private Property and the Constitution (1977). Richard Epstein mentions slavery in passing in a footnote and uses racial discrimination as an example. See RICHARD EPSTEIN, TAKINGS 335 n.7 (1986). Because Epstein, in places, contends he is doing history, he has less of an excuse. This tendency to ignore the impact of slavery on the law is not a new phenomenon. See JAMES WillaRd HURST, LAW AND THE CONDITIONS OF FREEDOM IN THE NineteENTH-CENTURY UNITED STATES (1956). Despite the fact that Hurst is writing immediately after Brown and during the Montgomery Bus Boycott, slavery is barely mentioned, and when it does appear, it is with little insight into the contribution of slavery to the problem: "Circumstances through the first threequarters of the century thus never called for a major test of attitudes toward protecting the status quo simply as such, unless one counts the issue of slavery as an instance." Id. at 25.

116. See A. Leon Higgenbotham, Jr., Book Review, 122 U. PA. L. REv. 1044, 1047 (1974) (noting that the failure of American legal education to properly address racial issues has contributed to our present inability to properly correct the resulting injustices). 
its colonial predecessor. Not all law has followed these constructions in the order that they will be discussed, but all American law as it interacts with the issue of race has been dependent on these notions. These constructions began in the frustrating chains of slavery, continued through the exhilaration of the Reconstruction and the tragedy of "Redemption," and have continued into the present imperfect relationship of blacks within the legal structure.

Black people in America went through three of these constructions of the legal relationship during slavery. Initially, the law largely ignored black slaves and treated them as non-beings. ${ }^{117}$ Eventually, the law evolved into a paternalistic system that treated blacks as lesser beings whoin white inasters and overseers needed to protect from their own ignorant, sloven, and evil nature. ${ }^{18}$ Finally, the slave law created legal rules that provided for legal limitations on the activities of slaves and

117. The Constitution referred to black slaves as "other persons." U.S. ConsT., art 1, $\$ 2$, cl. 3 . See A. LeON Higginbotham, JR., IN the MatTer of Color 22-26 (1978) (describing judicial refusal to recognize rights for slaves in colonial Virginia); see also Dellinger, Curse of Heaven, supra note 89, at $154-56$ (1987). Professor Dellinger argues that this conscious refusal to admit slavery explicitly or to acknowledge its legitimacy under the natural rights imbedded in the Constitution and the Declaration of Independence meant that the Constitution implicitly rejected the notion of slavery as being proper, and the idea of blacks as being inferior. However, one could just as easily argue that the Southerners who wanted to protect slavery in the Constitution could and did claim that the silence of the Constitution on the rights of blacks and slavery was an endorsement of a different status.

118. See, eg., W. JoRDan, supra note 6, at 103-110 (1968) (discussing the origin of the Slave Codes and the behaviors they were designed to regulate). The South Carolina black code, borrowed from Barbados, stated this purpose as late as 1735:

WHEREAS, the plantations and estates of this Province cannot be well and sufficiently managed and brought into use, without the labor and service of negroes and other slaves; and forasmuch as the said negroes and other slaves brought unto the people of the Province for that purpose, are of barbarous, wild, savage natures, and such as renders them wholly unqualified to be governed by the laws, customs, and practices of this Province; but that it is absolutely necessary, that such other constitutions laws and orders, should in this Province be made and enacted, for the good regulating and ordering of them, as may restrain the disorders, rapines and inhumanity to which they are naturally prone and inclined ....

$I d$. at 109-10. Jordan described the problem of paternalism in this way:

While the colonial slave codes seem at first sight to have been intended to discipline Negroes, to deny them freedoms available to other Americans, a very slight shift in perspective shows the codes in a different light: they aimed, paradoxically, at disciplining white men. Principally, the law told the white man, not the Negro, what he must do; the codes were for the eyes and ears of slaveowners....

Id. at 108.

Richard Wade describes the paternalism of the urban areas, where the courts and others tried to discipline and control the idleness and laziness of blacks. See Richard WADE, SLAVERY IN THE Cities: The South, 1820-1860, at 80-110 (1964); see also Herbert Gutman, The Black FamILY IN SLAVERY AND FREEDOM, 1750-1925, at 531-44 (1976) (describing the argument for the need during and after slavery for whites to protect blacks from their own inherent bad habits).

Eugene Genovese argues that the creation of paternalism was a product of the slaves' understanding that legal rules would not protect them; they thus strived for paternalistic protection instead of legal protection. See Eugene Genovese, Roll Jordan Roll: THe World the Slaves Made 49 (1976). 
their masters; in other words, the state stepped between slaves and masters and imposed external rules. ${ }^{119}$ Thus, there are three powerful constructions of law that slavery has bequeathed to legal interpretationignoring blacks altogether, treating blacks paternalistically, and creating limited legal rules to regulate white behavior toward blacks. 120 The postslavery period added a fourth powerful way of constructing the legal environment: The requirement that blacks, in participating in the legal environment, defer to the interests of the white majority. For this reason, American law has been and continues to be unequal and separate with respect to the interests of blacks.

119. See, e.g., Barbara Jeanne Fields, Slavery and Freedom on the Middle Ground 23-62 (1985) (Maryland's development of free black population and urban population of black slaves led to legal changes); W. JORDAN, supra note 6, at 103-10 (1968) (there was a need to develop rules to limit activities of white slave masters); R. WADE, supra note 118 (growth of free population and the development of changes in strict slavery system required the growth and development of legal rules and limitations which went beyond rules applicable in rural areas). This contrasts with Roman law, in which slaves were not public property but the responsibility of the owners. See A. WATSON, supra note 6, at 63-82 (1989). In the United States, slaves were severely restricted in their ability to do things. In many places they could not keep cattle or hire out their labor even with the approval of their master. The state prescribed what kind of conduct was necessary by both slave and master, and if the master did not inflict the stated penalty for certain slave offenses, it was infiicted on the slave by governmental authority. $I d$. at 66 .

120. In discussing this legal relationship, I emphasize the relationship of black slaves to the law. However, the law in the North and the South treated free blacks in ways that were very similar to the treatment of black slaves. Black "freeman" in the South were subject to an array of constantly changing rules that limited their rights and required them to be subordinate to whites of any station at any time. See Ira Berlin, Slaves Without MASTERs 316-40 (1974) (detailing the rights and privileges that free blacks were regularly denied). Free blacks of the North were also subjeet to a vast array of unequal and subordinating legal provisions. See, e.g., LEONARD P. CURRY, THE FREE BLACK IN URBAN AMERICA, 1800-1850, at 81-95 (1986) (describing legal provisions in the North and South limiting the freedom of blacks); JACQUE VoEgeli, FREE BUT NOT EQUAL 1-9 (1967) (describing the "color-caste system" present in every state).

All three of the ways of treating black slaves were inflicted on Northern blacks as well. For example, the Ohio legislature in 1839 passed a resolution that stated:

The blacks and mulattoes, who may be residents within this State, have no constitutional right to present their petitions to the General Assembly for any purpose whatsoever, and that any reception of such petitions on the part of the General Assembly is a mere act of privilege or policy and not imposed by any expressed or implied power of the constitution.

L. CuRry, supra, at 87 (citation omitted) (quoting FrANK QuILLIN, Color LINE IN OHIO 52 (1913)). This provision embodies all three principles of black treatment in American law. The resolution by implication denies citizenship to blacks who reside in the state, permitting the state to put them outside the law as if they did not exist. It suggests that the white General Assembly will consider such petitions if it chooses to, in other words, if the legislature believes that it is in the paternalistic interest of black people. Curry noted that "[w]hen blacks were brought before magistrates on any save the most serious charges, the court reporters made them figures of fun-exaggerating (or fabricating) their mannerisms, dialect, and ignorance of legal forms." Id. at 93. Blacks had some rights to use the legal process and there were some limits on how whites could treat black freeman in the North, but this limitation was often more in form than substance. If the legal rules were not formally being cut back, then they were being eliminated by ridicule and disinterest on the part of judges and law enforcement personnel. Id. 
These four different ways of viewing black Americans are not simply an evolutionary progression: The law continues to embody all four of these elements in its interpretation of the legal protections available to black Americans. In this sense, there is no past or future for the treatment of black citizens-imstead there is only a mushy present that retains all of its past even as it alters the forms of black treatment.

In many ways, the legal process has come full circle. The experience of black Americans when they first came to the Uinited States was that they were often ignored by the law. ${ }^{121}$ And judges, through the doctrine of color-blind neutrality, are again ignoring the concerns of blacks in their decisions.

A recent example of this phenomenon is Rankin v. McPherson. ${ }^{122}$ Ardith McPherson, a black woman, was working as a deputy constable but was still within the probationary einployment period. ${ }^{123}$ Ms. McPherson's position did not require her-indeed, did not permit her-to act as a hicensed police officer. ${ }^{124}$ On the day that President Reagan was shot, she said to her boyfriend, who also was an employee of the constable's office, "[I]f they go for him [Reagan] again, I hope they get him."125 Ms. McPherson was fired from lier job for inaking this statement and subsequently she sued to be reinstated. ${ }^{126}$ The Supreme Court held that she was wrongfully fired because, given lier job, the state's interest in dismissing an employee witl such views did not outweigh the employee's first ainendinent interests. The inost fascinatimg aspect of the case, however, is how the different justices dealt with the reality of Ms. McPherson's race.

Justice Marshall, who wrote the majority opinion, specifically mentioned that Ms. McPlierson is black-a matter that neitlier Justice Powell nor Justice Scalia included in tleir opimons. Leaving race out of their opimions was not an accident. Both Justices Powell and Scalia believe that race is irrelevant-even when it is crucial to understanding the context that gives rise to a case. The law seems to take this color-blind approacl most often when a color-conscious approach would lend perspective to the situation of a black participant in the legal process.

Why, then, does Justice Marshall inention that Ms. McPherson was black? The answer is clear from the perspective of the black experience. Much of the lives of black people are spent in anger over real and

121. See JoHn B. Boles, BLACK SOUTHERNers: 1619-1869, at 20-24 (1984).

122. 483 U.S. 378 (1987).

123. Id. at 380 .

124. Id.

125. Id. at 381 .

126. Id. at 382 . 
imagined slights by white landlords, supervisors, and bosses. In a country in which black perspectives are so out of line with those of others in the country, ${ }^{127}$ our only power is to speak to ourselves. Justice Marshall, author of much public criticisin of President Reagan and President Bush, ${ }^{128}$ often uses the dialect of black people-a dialect that permits black people to criticize powerful people in a somewhat veiled fashion. Justice Marshall understood Ms. McPherson's comments in this hight and he sought to infuse his opinion with a fact essential to the under-

127. For example, in $1984,63 \%$ of whites and only $11 \%$ of blacks voted for Ronald Reagan. See ABC News Exit Poll cited in Paul Light \& Celinda Lake, The Election: Candidates, Strategies, and Decisions in The Elections of 1984, at 106 (Michael Nelson ed. 1985). In 1980, 12\% of blacks voted for Reagan while a majority of whites in the country voted for him. Reagan, of course, is not the only recent American President to earn the ire of black Americans. After a white mob in South Boston attacked school buses taking black children to white schools, President Ford said that he was opposed to the court orders that required busing of Boston's public school children. At a news conference, Ford exclaimed, "I have consistently opposed forced busing to achieve racial balance as a solution to quality education, and therefore, I respectfully disagree with the judge's order [in Morgan v. Kerrigan, 379 F. Supp. 410 (D. Mass. 1974), aff'd sub nom. Morgan v. Kerrigan, 509 F.2d 580 (1st Cir. 1974), cert. denied, 421 U.S. 963 (1975)]." Roy Wilkins, then-Executive Director of the NAACP, recognized the danger that might arise as a result of the President's remarks. Wilkins explained that these comments would encourage further resistance among whites, and "could result in the maiming or killing of black children." William Chapman \& William Claiborne, Ford Decries Boston School Busing Order, Wash. Post, Oct. 10, 1974, at A1, col. 4.

Richard Pryor often talks about "Mudbone," who is mistreated by his white mistress and whose only recourse is to get mad, or do something and leave the state of Mississippi. Like this fictional character, black people seldom expect to have the opportunity to tell off offending politicians or deal with even more immediate problems like their bosses. See Richard Pryor, Mudbone Introduction, Is It Something I Said? (Reprise Records 1975).

128. See Lionel Barber, Judge Scoffs at Bush Nominee, Financial T1MEs, July 28, 1990, at 3; Marshall's Ire: A Justice v. The President, N.Y. Times, Sept. 13, 1987, §4, at 4, col. 6. 
standing of the context-Ms. McPherson's race. ${ }^{129}$ Race matters to Justice Marshall just as it does not matter to his colleagues. ${ }^{130}$

Judges do not always tell us when and for what purpose a fact is important, but the absence of race considerations in general is no accident; it reflects the view that race is irrelevant to understanding the circumstances surrounding an incident, despite the fact that, in reality, race colors most situations in which whites and blacks interact.

It is not simply that some white judges did not mention that Ms. McPherson was black. ${ }^{131}$ For those judges, the fact that a party is black does not change the perspective from which any issue should be examined. ${ }^{132}$ However, because the world is implicitly examined from the

129. Rankin, 483 U.S. at 382-86. However, Justice Marshall did not use all that he knew. He noted in footnote four of that opinion:

Rankin testified that, when he asked McPherson whether she meant the remark, she replied, "I sure do." ... In neither of its opinions in this case did the District Court make an explicit finding regarding which version of this conflicting testimony it found credible. ... We note that the question whether McPherson "meant" the statement is ambiguous. Assuming that McPherson told Rankin she "meant it," McPherson might think she had said that she "meant" that she disliked the President and would not mind if he were dead, while Rankin might believe that McPherson "meant" to indicate approval of, or in any event hope for, political assassination. This ambiguity makes evident the need for carefully conducted hearings and precise and complete findings of fact.

Id. at 382 n.4. Justice Marshall understands that the factual finding is irrelevant to whether Ms. McPherson represents a danger to either the criminal justice system or President Reagan. Ms. McPherson's remarks simply refiected the irritation many black people feel toward former President Reagan.

The discussion of what was meant by Ms. McPherson's words assumes that it is possible to find a definitive meaning to the words independent of context. Furthermore, it is possible for Ms. McPherson to mean several different things. Perhaps part of the unstated premise is that Ms. McPherson should be careful to mean something to those who would overhear what she said. Critical theory teaches us that there is no simple or easy way to find or enforce meaning in such situations. See Barbara HerRnstein Smith, Contingencies of Value (1988).

130. The only possible reason to ignore the reality of Ms. McPherson's race was that Justice Marshall's colleagues would not understand the power and truth of this fact. By dwelling on a matter that his white colleagues cannot understand, Justice Marshall, in a sense, plays a trick on the Court.

131. The white judges who examined this case in the district court and on the Fifth Circuit (with divergent conclusions) also did not mention that McPherson was black. See McPherson v. Rankin, 786 F.2d 1233 (1985) (Higginbotham, J.). Note, however, that in Hill v. City of Houston, Judge Higginbotham does refer to the homosexuality of the plaintiff:

At the time of his arrest, Raymond Hill was forty-one years old, a homosexual, and a resident of Houston, Texas ... and helped form the Houston Gay Political Caucus. He has since been a vocal advocate of the homosexual cause, and was on the Caucus' Board of Directors at the time of trial. In addition to employment as a paralegal, he also did radio shows for a local community service broadcasting station and, accordingly, carried a press badge. ... We draw out these background facts, not to suggest that Hill is entitled to any greater or lesser first amendment protection because of them, but in order to provide a more complete picture of the individual who confronted Officers Kelley and Holtsclaw.

Hill v. City of Houston, 789 F.2d 1103, 1116-17 \& n.1 (5th Cir. 1986) (Higginbotham, J., dissenting).

132. I am not suggesting that there is some moral superiority on the part of black judges to see all issues. Note, for example, the failure of most of the justices (except for Justice O'Connor) to 
perspective of the white majority, this claim of colorblindness actually discriminates. Justice Marshall understands that if the law is to be truly fair it must be in touch with the black experience.

Recent examples of the problem of white lack of awareness of racial involvement can be found in Justice Scalia's opinion in Rankin. Justice Scalia put the question in its clearest hight at the very beginning of his dissenting opinion. He stated,

I agree with the proposition, felicitously put by Constable Rankin's counsel, that no law enforcement agency is required by the First Amendment to permit one of its employees to "ride with the cops and cheer for the robbers. ..." The issue in this case is whether Constable Rankin, a law enforcement official, is prohibited by the First Amendment from preventing his employees from saying of the attempted assassination of President Reagan- on the job and within hearing of other employees- "If they go for him again, I hope they get him."133

Why does Justice Scalia find it important that Ms. McPherson was on tlie job? Arguably, Ms. McPherson was not on the job but on her lunch break when she made the statement-and it was made in a way that makes it clear that Ms. McPherson did not intend for it to be "within the hearing of other employees." Why then does Justice Scalia reach out to find facts that are not there in order to make his case stronger? ${ }^{134}$

A careful reading of Justice Scalia's dissenting opinion suggests that, in fact, race is the determining factor in shaping low he perceives this case. The real reason he is concerned about the statement has nothing to do with how this statement will inpact the morale of the police force. (Tlis incident, after all, happened some 2000 miles away froin the attempted assassination of then-President Reagan, in another jurisdiction.) In iny view, Justice Scalia's real concern is that Ms. McPlierson lias over-

review the shocking decision, rendered by the district court and upheld by the court of appeals, that Christine Craft could be dismissed from her job as a television anchor because she was not attractive enough. See Craft v. Metromedia, 766 F.2d 1205 (8th Cir. 1985), cert. denied, 475 U.S. 1058 (1986). It may be that male judges have a hard time seeing the sexism associated with imposing higher and different standards on female anchors than on male ones. I do not believe that Justice Marshall would have failed to see the problems associated with such an issue if it had been a more typical racial setting. In Price Waterhouse v. Hopkins, 490 U.S. 228, 239-42, 250-52 (1989), a majority of the Supreme Court found that sex stereotyping may be actionable discrimination under Title VII and approved a lower court finding of such stereotyping.

133. Rankin, 483 U.S. at 394 (Scalia, J., dissenting) (citations omitted and emphasis added).

134. To strengthen his case, Justice Scalia could have argued that such statements were equivalent to the statements of white police officers in support of the Ku Klux Klan in McMullen v. Carson, 754 F.2d 936 (11th Cir. 1985). But this argument is not available to Justice Scalia; although he would probably view race as significant in McMullen, he cannot see that race plays a role in Rankin. In McMullen a white sheriff's office employee who publicly acknowledged his Klan status on a television program was held dischargeable because of the inability of the city to perform its functions with Klan employees, and because the balance between the employees' right and that of the employer favors the employer. Id. at $938-60$. 
stepped the permissible bounds of her right to be black-by which I mean the right to take personally the political statements made by a white politician that seemed directed at black people. ${ }^{135}$ Justice Scalia believes that people who are given the honor of being public servants have no right to express such hostility toward the President of the United States.

It is important to understand what the vast majority of black Americans understand about the statement of Ms. McPherson; she meant the statement only as a part of the hyperbole to which black anger is limited in the United States. She did not mean for these statements, which were directed to her black fiancé, to be overheard by her white colleagues. It is also important to understand what all black people know, which is that they speak more than one language, and the language at home is often angry and always different from the common language spoken in public.

Justice Marshall alone acknowledged this possibility in the majority opinion, yet he stopped short of an exphcitly race-conscious perspective on Rankin. Instead, he couched this understanding in terms that were consistent with the Black Jurisprudence of which he has been a major architect. Marshall concluded,

McPherson's employment-related interaction with the constable was apparently neghigible. Her duties were clearly clerical and were limited

135. The Reagan campaign in 1980 began in Philadelphia, Mississippi, one of the homes of the Klan. Philadelphia is in the county where three civil rights workers were murdered and buried in an earthen dam in the 1960s. President Rcagan began that campaign by saying that he stood for States' Rights. Wilkins, Smiling Racism: Ronald Reagan's Race Policies, The Nation, Nov. 3, 1984, at 437. The slogan "States' Rights" was one of the war cries of the white councils that indirectly ran Mississippi in the early 1960 s.

Furthermore, the Reagan Administration adopted a number of positions that were perceived as anti-black. A Los Angeles Times editorial stated, "In seven years this [Reagan] Justice Department has campaigned to ... abolish abortion and affirmative action, to secure tax exemptions for private schools that discriminate against blacks and to abandon the exclusionary rule." Call to Battle, Los Angeles Times, Mar. 5, 1988, (Metro) at 8, col. 1. See George Curry, Reagan Blasted on Racism Issue, Chicago Tribune, Jan. 15, 1988, at C3, col. 1. ("The president of the National Urban League accused the Reagan administration Thursday of creating a national climate that fosters racism. At a news conference to release its 'State of Black America,' an annual assessment of the status of blacks, the civil rights group's leader, John Jacob, aecused the administration of 'creating a climate in which racism has been allowed to fester and grow.' ").

In a United Press International release, Terrel Bell, the first Secretary of Education in the Reagan administration, reported the atmosphere among some key Reagan aides as resentful of blacks.

Bell said he never heard racist jokes or sexist comments from the president, Cabinet mem-

bers or colleagues but there "was the evidence of apparent bias among mid-level right-wing staffers in the White House. ... I was shocked to hear their sick humor and racist cliches."

... "For example, when the bill to establish a national holiday to honor Martin Luther

King Jr. was before the president for his signature or veto, these bigots referred to Dr.

King as 'Martin Lucifer Coon!' . . . They delighted in making other slurs. Arabs were called 'sand niggers.'"

Tamara Henry, Bell: Some Administration Staff had 'Resentment' Toward Minorities, United Press Int'1 Press Release, Jan. 22, 1988. 
solely to the civil process function of the Constable's office. There is no indication that she would ever be in a position to further-or indeed to have any involvement with-the minimal law enforcement activity engaged in by the Constable's office. Given the function of the agency, McPherson's position in the office, and the nature of her statement, we are not persuaded that Rankin's interest in discharging her outweighed her rights under the First Amendment. ${ }^{136}$

Justice Marshall's opinion focused on the nature of Ms. McPherson's job in concluding that her comment was so unimportant that the Court need not look at how much protection the first amendment provides for her stateinents. However, Marshall just as easily could have focused on the statements theinselves, concluding that since they were imsubstantial and not personal they were protected, leaving for another day whether soine stateinents inade by soine officers would amount to such a direct threat to the interests of an employer that those interests would have to be balanced against first ainendinent concerns. Justice Marshall's choice clearly will influence concerns outside the confines of this case. His opinion urges judges to look at the status of einployees in evaluating the protection given their speech. The Court's approach provided the most limited protection that could have been provided to black einployees without permitting their discharge.

The Court implicitly, and Justice Scalia exphicitly, asks black employees to subordinate their concerns to the conventional views of the white majority-if their position is sufficiently powerful to warrant such conformity. The concession may seem sinall-after all, it ouly eliminates a small part of the possible discourse of black people-but the inpact of that change is substantial for the public discourse and for how black people react to employinent. Black anger legitimately and nonthreateningly addressed toward einployers or other whites is seen as a legitimate rationale for discipline and discharge. The growing number of cases in the einployment context that charge employers in racial discrimination cases with retaliation is stark evidence of this fact. ${ }^{137}$

A similar issue of ignoring the concerns of blacks appears in the Supreine Court's most important recent exainination of the death penalty and race. In $M c$ Cleskey v. Kemp, ${ }^{138}$ Justice Powell stated that the fact that blacks are executed more frequently than whites, and were executed at rates several times greater (at statistically significant levels) when they

136. Rankin, 483 U.S. 378, 392 (1986).

137. The total number of charges for race-related retaliation under Title VII has more than doubled between the fiscal years of 1981 and 1990. In 1981, the total number of charges for racerelated retaliation filed with the EEOC was 3,470, and, in 1990, the number had grown to 7,161 . Records of EEOC (available from author).

138. 481 U.S. 279 (1987). 
kill whites than when they kill blacks or when whites kill other whites, does not call into question the basic fairness of the criminal justice system.

Race is viewed as irrelevant by the five-justice majority in $\mathrm{McCles}$ key. They ignore black concerns-concerns that are considered irrelevant to the fairness of the death penalty. The Court argued that to accept any other approach would lead to a slippery slope from which the death penalty system would not be able to escape. ${ }^{139}$ This goal certainly was part of the intention of the NAACP Legal Defense Fund to force the Court to acknowledge the racial inequities in administration of the death penalty. But the Court provided a very unsatisfactory answer to the questions posed. The Supreme Court permitted the states to assume that black people do not have a right to be treated equally as long as the system seems fair to white victims. From the perspective of white victims, it is fair to hold black criminals to a higher and different standard. Being a black victim or a black perpetrator of crimes against black people does not count as heavily-despite clear evidence that it is an important part of the decisional process of the judicial system. Race plays a part in the sentencing of criminals everywhere in this country because race matters to the participants in the system, both black and white. The problem for black people is that white people use the imposition of the death penalty to keep black people in their place. This use is an improper one, and as Justice Brennan suggests, it is up to the state to provide a nonracist method of imposing the death penalty. ${ }^{140}$

\footnotetext{
139. The Court held that

[I]f we accepted McCleskey's claim that racial bias has impermissibly tainted the capital sentencing decision, we could soon be faced with similar claims as to other types of penalty. Moreover, the claim that his sentence rests on the irrelevant factor of race easily could be extended to apply to claims based on unexplained discrepancies that correlate to membership in other minority groups, and even to gender. Similarly, since McCleskey's claim relates to the race of his victim, other claims could apply with equally logical force to statistical disparities that correlate with the race or sex of other actors in the criminal justice system, such as defense attorneys, or judges. ... As these examples illustrate, there is no limiting principle to the type of challenge brought by McCleskey. The Constitution does not require that a State eliminate any demonstrable disparity that correlates with a potentially irrelevant factor in order to operate a criminal justice system that includes capital punishment.
}

McCleskey, 481 U.S. at 314-19 (emphasis added and footnotes omitted). This argument ignores the history of race relations in this country, id. at 334 (Brennan, J., dissenting), and also suggests the weakness inherent in the use of statistics to prove discrimination. There will be numerous situations where the small numbers involved or the correlation between race and other variables masks the racism in criminal law or employment decisions. The majority does not understand the limitations inherent in statistics. See id. at 295 n.14. It is not possible to develop a common standard for juries involved in sentencing defendants to death like the common standards developed in employment settings.

140. McCleskey, 481 U.S. at 328 (Brennan, J., dissenting). 
Does Justice Powell really believe that race is irrelevant, or is he really contending that as long as it is not done too explicitly it is appropriate for juries and employers to use race in making their decisions? It is more likely that he means the latter. This implicit permission to use race does not lead to a colorblind society nor to a color neutral society, although those who urge it on us may believe so. The Court is unwilling to see the racism inherent in this failure to acknowledge that race matters. There are few in America who will admit that race does not cloud the decisions of juries and employers, but there are more and more participants who argue that law-in all of its inajestic neutrality-ought to ignore race.

The $M c$ Cleskey case also has implications for how the courts are likely to treat the question of discrimination in the future. The Supreme Court already has stated that some discrimination in the employment process and in allocating subcontracting dollars is not remediable. ${ }^{141}$ This view is a stark reminder of the way in which the Court will and will not use statistics to prove discrimination. ${ }^{142}$

\section{The SHORT, RECENT History OF BlACK LEgal ScholarshiP}

The nascent movement toward a Black Legal Scholarship has reacted to all four parts of the historical treatment of race in the law. I demonstrate in this Part that the current generation of Black Legal Scholars ${ }^{143}$ has identified the problem but has been reluctant to admit

141. See City of Richmond v. J.A. Croson Co., 488 U.S. 469 (1989).

142. The McCleskey Court discussed with approval the findings by the district court that Professor David Baldus' study methodology was flawed. McCleskey, 481 U.S. at 288 n.6. 1ncluded in this discussion were the arguments that the 230 -variable model is unable to explain more than $48 \%$ of the variance in results and that race is highly correlated with other variables. There are several problems with this analysis that go to the heart of how to interpret statistics and discrimination. As the Court itself implicitly acknowledged in its decision in Griggs v. Duke Power Co., 401 U.S. 424 (1971), neutral factors can disguise racial factors. To look for smoking guns in the debris of such complicated statistical matters is likely to lead to a situation where race does matter. More importantly, statistics are used by the relevant actors in employment and criminal law areas, but are ignored by the courts.

In addition, the failure of a model to explain only part of the results of a complicated process is not unusual. Statistically, a model with a very small $R$-squared may be a better model than one which purports to explain all of the variance. Good models start with good theory, and without good theory, there are no effective ways of determining the appropriate results.

143. Because of the length of this Article, I have not had the opportunity to deal with the more recent history of black legal scholars' contributions in the 1970s. I think the contributions of Professor Derrick Bell at Harvard, Professor James Jones at Wisconsin, Judge and former Professor Harry Edwards at Michigan and Harvard in the 1970s, Professor Robert Belton at Vanderbilt and Professor Eleanor Holmes Norton at Georgetown in the early 1980s-to name just a few of the black scholars-are the potential subject of scholarly treatment. There is much that we could learn from their scholarship, but it is not possible to be fair to that subject in this Article. I believe that a careful examination of their scholarship will support my thesis about Black Jurisprudence and Black Legal 
that race ought to be included in our analysis independent of other tools of legal scholarship. I argue that in order for Black Legal Scholarship to develop and for the law to perform the tasks that we want it to undertake, the practitioners of legal scholarship-black and white-must do a better job of dealing with race.

Until recently, most legal scholarship by blacks took place outside American law schools. ${ }^{144}$ It has been action-oriented and focused on court decisions. This has been the result of several factors. Predominately white law schools have not been very interested in having blacks participate as students, teachers, or scholars in the legal process. There have been exceptions: Derrick Bell at Harvard Law School and the University of Oregon; William Ming at the University of Chicago; John R. Wilkins at the University of California; Professor and Ambassador C. Clyde Ferguson at Harvard, Rutgers, and as Dean of Howard University Law School; Charles W. Quick at Wayne State Law School and the University of Illinois; and Harry E. Groves at the University of Cincinnati College of Law, the University of North Carolina, and North Carolina Central University. These scholars made notable contributions to legal scholarship. But some of these efforts were ignored by the scholarship that predominated in white law schools, and for black scholars at predominately black schools it has been (and probably still is) difficult to get either the resources or the time away from the classroom that is necessary for pure research.

Certainly, the attitude taken by two illustrious deans of Howard Law School, William Hastie and Charles Houston, suggests that they felt their primary task was to train a generation of lawyers who could participate in the legal struggle for justice under the law. ${ }^{145}$ However, this view of legal education taken by black scholars, in both predominately white and black schools, although different in perspective and concern from the view of white scholars, did not permit an attack on the ethnocentric nature of American legal scholarship.

The small number of blacks who were in the legal academy and who had time to do research wrote with the assumption that the then-current

Scholarship, but some of their early work anticipates the scholarship that some of the new black scholars have begun.

144. See, e.g. W.E.B. Du Bois, Black Reconstruction in America 1860-1880 (1962); W.E.B. Du Bois, The Philadelphia Negro (1967). Current black legal scholars havc also begun to look at the accomplishments of earlier black scholars. See J. Clay Smith, Principles Supplementing the Houstonian School of Jurisprudence, 32 How. L.J. 493 (1989). It may be that there was morc early scholarship than we are presently aware of, but it should also be clear that much of that scholarship was ignored by white writers.

145. See August Meier \& Elliott Rudwick, Attorneys Black and White: A Case Study of Race Relations within the NAACP, in ALONG THE COLOR LINE, supra note 37, at 128-56. 
structure of legal discourse was fixed. As an example, Professor Ming argued that the Supreme Court's opinion in the Restrictive Covenant Cases $^{146}$ provided at least one avenue that had been closed to blacks by the Civil Rights Cases. Professor Ming pointed out that the Court, although denying the enforceability of the Reconstruction civil rights statutes with respect to private behavior, had acknowledged that blacks had rights. ${ }^{147}$ The majority in the Civil Rights Cases argued,

An individual cannot deprive a man of his right to vote, to hold property, to buy and sell, to sue in the courts, or to be a witness or a juror; he may, by force or fraud, interfere with the enjoyment of the right in a particular case; he may commit an assault against the person ... or slander the good name of a fellow citizen; but, unless protected in these wrongful acts by some shield of State law or State authority, he cannot destroy or injure the right; he will only render himself amenable to satisfaction or punishment .... ${ }^{148}$

Professor Ming picked up on a question asked fifteen years before by Professor Robert Hale, ${ }^{149}$ and he argued that the Restrictive Covenant Cases suggested that the fourteenth amendment requires states to provide affirmative protection against the acts of providers of public accommodations. ${ }^{150}$ Professor Ming's analysis was ahead of its time in several ways. He successfully incorporated the latest social science research into his article ${ }^{151}$ and his economic analysis, especially for the time, was very good. ${ }^{152}$

Although Professor Ming did a first-class analysis of the early race cases, he did not question the assumption that the Constitution is what the Supreme Court has discerned from the entrails of the Framers and the post-bellum drafters of the thirteenth and fourteenth amendments.

146. Shelley v. Kraemer, 334 U.S. 1 (1948); Hurd v. Hodge, 334 U.S. 24 (1948) [hereinafter Restrictive Covenant Cases] (holding that it was state action for state courts to enforce private contracts that excluded purchasers of property on racial grounds).

147. Compare the sophisticated analysis of this history in the article by Professor Ming with the discussion in Judge Bork's new book. R. BORK, THE TEMPTING OF AMERICA supra note 91, at 15153,324 . Judge Bork does not understand the historical background of this case. He writes as if Shelley were invented out of whole cloth.

148. The Civil Rights Cases, 109 U.S. 3, 17-18 (1883) (emphasis added). See Ming, Racial Restrictions, supra note 24, at 203, 236-37 (1948).

149. See Ming, Racial Restrictions, supra note 24, at 238 (quoting Robert Hale, Force and the State: A Comparison of "Political" and "Economic" Compulsion, 35 Colum. L. Rev. 149, 185 (1935)).

150. See id. at 238.

151. See id. at 208-11, nn.18-23.

152. See id. at 217-20. Ming argues that some of the suggested ways of getting around the decision in the Restrictive Covenant Cases are unlikely to be adopted because of their cost to the participants. He almost makes the point that the economic rationale for the Restrictive Covenant Cases is that it provides a cheap method for whites to enforce their prejudices and that most of the alternatives simply are too costly. 
Race did not inatter to Professor Ming's analysis precisely because he understood that it did not matter to the Supreme Court or to his University of Chicago colleagues. This assumption was not challenged directly by Ming or his black contemporaries in the law schools in the 1950s and 1960s.

But this does not mean that these often ingenious lawyers did not challenge the system. They altered the system so that the scope of the equal protection clause was extended not only to blacks and other racial minorities but to women, aliens, illegitimate children, and occasionally indigents-and the scope of the rights of all Americans was enlarged. ${ }^{153}$ Although blacks were successful in challenging racial restrictions and impediments before Brown, they never have shaken the view expressed repeatedly by the Court that the law has to be viewed through the lenses of white Americans. This transformation accepts the legal world as it is, a product of the white framers and interpreters. Justice Harlan put it best just before he excoriated the majority's opinion in Plessy. Harlan said:

The white race deems itself to be the dominant race in this country. And so it is, in prestige, in achievements, in education, in wealth and in power. So, I doubt not, it will continue to be for all time, if it remains true to its great heritage and holds fast to the principles of constitutional liberty. But in view of the Constitution, in the eye of the law, there is in this country no superior, dominant, ruling class of citizens. There is no caste here. Our Constitution is color-blind, and neither knows nor tolerates classes among citizens. In respect of civil rights all citizens are equal before the law. ${ }^{154}$

Justice Harlan was wrong. The Constitution was written from the perspective of white citizens with only their interests in mind. When the Constitution said "we the people," it is very likely that they did not have black people, free or slave, in mind. Of course, Chief Justice Taney had been wrong when he suggested that the Constitution had provided no rights for blacks. ${ }^{155}$ Blacks, even slaves and those not born in America, had been accorded rights under the state and federal constitutions. The problem was that no white founder believed that these rights should include participation by black Americans in establishing the basic constitutional structure.

Several black legal scholars recently have raised the importance of the black perspective on legal issues. There are five recent and important examples of black legal scholarship: an article and a short comment by

153. See D. BELL, RACE, RACISM AND AMERICAN LAw, supra note 96.

154. Plessy v. Ferguson, 163 U.S. 537, 559 (1896) (Harlan, J., dissenting) (emphasis added).

155. Dred Scott v. Sandford, 60 U.S. (19 How.) 393 (1857). 
Randall Kennedy, 156 a Foreword to the Harvard Law Review by Derrick Bell, ${ }^{157}$ a series of articles by Patricia Williams on the notion of rights, ${ }^{158}$ and an article by Charles Lawrence. ${ }^{159}$ In each, the author takes on aspects of the legal scholarship that I have tried to describe, but none has gone far enough in actually breaking away from the assumptions that underlie Black Jurisprudence. Each author deals with different aspects of discrimination that are products of the historical treatment of blacks in our legal system. Several of the authors deal with aspects of the paternalism in the law. Some question the notions of deference inherent in traditional interpretations of the Constitution and statutes. None of these powerful analyses, however, are able to step completely outside the notions of race inherited from our constitutional and judicial past (and no doubt neither will I).

This failure to completely reject the assumptions that underlie the legal rules produced by Black Jurisprudence also is true of the black nonlawyers who have commented on legal questions concerning the position of black Americans for the last twenty-five years-primarily the black social scientists: Thomas Sowell, ${ }^{160}$ Glenn Loury, ${ }^{161}$ and William Julius Wilson, ${ }^{162}$ and the black historian, Harold Cruse, ${ }^{163}$ who have written critically about the civil rights movement and its objectives.

In an article in the 100th anniversary issue of the Harvard Law Review, Philip Elman described much of the gains of the civil rights era as the product of the fortuitous actions of Philip Elman and Justice Frankfurter. ${ }^{164}$ In his brief response, Professor Kennedy noted that Elman's view is paternalistic: "One of the problems with Elman's analysis is its parochialism; he views the situation wholly from the perspective of the jus-

156. R. Kennedy, A Reply to Philip Elman, supra note 5; R. Kennedy, Race Relations Law and the Tradition of Celebration, supra note 5.

157. Bell, Foreword, supra note 25; see also Derrick Bell, ANd We ARE Not SAved (1987); Derrick Bell, Brown v. Board of Education and the Interest-Convergence Dilemma, 93 HARV. L. REV. 518 (1980) [hereinafter Bell, Interest-Convergence] (interests of races converged in Brown); Derrick Bell, Racial Remediation: An Historical Perspective on Current Conditions, 52 Notre DAME L. REV. 5 (1976) (white political pressure for racial superiority predicted to continue).

158. Patricia Williams, Alchemical Notes: Reconstructing Ideals from Deconstructed Rights, 22 HARV. C.R.-C.L. L. REv. 401 (1987) [hereinafter P. Williams, Alchemical Notes].

159. Charles Lawrence III, The Id, the Ego, and Equal Protection: Reckoning with Unconscious Racism, 39 STAN. L. REV. 317 (1987).

160. Thomas Sowell, The EConomics and Politics of Race 199-202 (1983).

161. Glenn Loury, "Matters of Color"-Blacks and The Constitutional Order, 86 Public INTEREST, Winter 1987, at 109.

162. William Julius Wilson, The Truly Disadvantaged 109-24 (1987).

163. H. CRUSE, supra note 39.

164. Philip Elman, The Solicitor General's Office, Justice Frankfurter, and Civil Rights Litigation, 1946-1960: An Oral History, 100 HARv. L. Rev. 817 (1987). 
tices."165 Kennedy does not deal with the question of why that is important, but he makes clear that Philip Elman's unstated premise of the white salvation of blacks is inappropriate. In rejecting Elman's claims of authority over civil rights progress, Kennedy takes the first step toward Black Legal Scholarship.

Professor Charles Lawrence outlined the argument for how to frame the question of race by asking:

What is the neutral principle that the equal protection clause embodies? And why would that principle encompass intentional racial stigmatization but not those cases identified by the cultural meaning test? .... [W] hen one finds that intentional racial discrimination is morally reprehensible but that unconscious racial stigmatization is not, one has made a value choice that defines the "neutral" principle of antidiscrimination in terms that adopt one world view and reject another. ${ }^{166}$

Professor Lawrence understood that neutral principles are the straitjacket that prevents judges from dealing with unconscious racism. Yet he was unwilling to attack the problem at its source-race. He attempted to cast his argument in the shadow of the arguments by traditional liberals, such as John Hart Ely and Paul Brest, and to respond to the more radical arguments of Alan Freeman. ${ }^{167}$ However, his efforts to tie his worldview into the liberals' critiques of current court and legal dogma fail precisely because these critiques ultimately take for granted the perspective of the white world. ${ }^{168}$

The confines of this Article do not permit a full treatment of all the arguments of these "traditional" liberal scholars, but it is sufficient to deal with those of Alan Freeman. ${ }^{169}$ Freeman argued that the world should be viewed historically from the perspective of victims and perpetrators, and that American law has adopted the view of the perpetrators and not the victims in depicting the changing world. Freeman argued,

The Brown case surely had to do with more than education. It was the official American statement that racial discrimination had become illegal (and immoral). The meaning of such a statement, to a black American in the fifties (or even now) must include an expectation that there will be, when the task is completed, some significant change in the conditions of life that one associates with the past practices of discrimi-

165. R. Kennedy, A Reply to Philip Elman, supra note 5, at 1947 (emphasis added).

166. Lawrence, supra note 159 , at 383-84 (emphasis added).

167. See Alan Freeman, Racism, Rights and the Quest for Equality of Opportunity: A Critical Legal Essay, 23 HARV. C.R.-C.L. L. REv. 295 (1988).

168. See id. at 383-88.

169. See Alan Freeman, School Desegregation Law: Promise, Contradiction, Rationalization, in Shades of Brown: NeW Perspectives on School Desegregation 71 (Derrick Bell ed. 1980) [hereinafter SHADES OF BROWN]. 
nation-segregated schools, lack of jobs, the worst jobs, lack of political power. ${ }^{170}$

Freeman went on to characterize civil rights law in the following fashion:

The present goal would seem to be to legitimize the accomplishments of civil rights law by emphasizing and displaying a small but successful black middle class, and seeking to gain its allegiance while ignoring the victim perspective claims of the vast and disproportionate numbers of poor and unemployed black people.

Thus, despite the uniqueness of race as an historical problem of oppression, it cannot be remedied alone unless one is willing to accept nothing more than token bourgeoisification within the structure of a presupposed system of equality of opportunity -in short, one must become part of the legitimation process. To challenge that limited view is to tackle the pretense of equality of opportunity directly, and to see it for what it is in relation to class structure. ${ }^{171}$

Freeman asked the appropriate question-how should black people's perspective contribute to looking at the problem of race? His answer nonetheless contained the same mistake as the traditional legal analysis. Freeman was unable to transform his real sympathy for black victims into a black perspective on equal protection and Brown. Brown did substantially change the world. Freeman ultimately was unable to see these changes because he viewed Brown from the perspective of the majority of our society. The decision was not simply the product of the concerns of the Supreme Court. The changes that took place not only were accomplished by the actions of nine white justices, but were the result of the planning and the blood of our black parents and grandparents, and some of the efforts of the people of my generation. To ignore the changes that Brown created is to misunderstand the conditions in which black people existed before the Court acted. Black people always have known that freedom would not be won in a day, even if they have not always expressed this concern. The role of the courts in providing change for black people will always partially be a product of the changes created by the black people. ${ }^{172}$ Black Americans also understand that both of these kinds of changes are real. ${ }^{173}$

170. Id. at 73 .

171. Id. at 88 (emphasis added); see also Freeman, supra note 167. Professor Freeman deals explicitly with the difficulty of being white and writing on issues of race and how he believes the issues play out for him. Richard Delgado, however, argues that there are some points about racism that Alan Freeman cannot see as a white person. See Richard Delgado, Critical Legal Studies and the Realities of Race-Does the Fundamental Contradiction have a Corollary?, 23 HARV. C.R.-C.L. L. REV. 407 (1988).

172. See H. GuTMAN, supra note 118 , at 3-44.

173. Black people even sometimes suggest that they believe that there has been no change when in fact they mean, if I read them correctly, that black people have exaggerated the gains. See Bell, Interest-Convergence, in SHADES OF BROWN, supra note 169, at 91. 
Freeman misunderstands this perspective because he has not successfully adopted the position of the black victim. Instead, he remains outside and above the black victim and suggests what ought to be done to save her. I do not mean to suggest that Freeman's effort is not useful, but rather that he has not done what he claims to have done. This point is clearest in the last part of the quoted passage. For Freeman, indeed for all Critical Legal Studies adherents, race does not matter outside its interaction with class and other concerns. Class matters, and so does race, but the law has to deal with the racial question irrespective of the extent to which class concerns are addressed. ${ }^{174}$

Charles Lawrence understands that there is a problem with the Freeman perspective. Yet, in The Id, the Ego, and Equal Protection, he was unable to find the true problem, because he was not quite willing to argue that race matters in and of itself-not disguised as class or immersed in other claims of justice or neutrality. Race matters and must be dealt with independently of these other important concerns. Lawrence argued that psychological perspectives can help us to understand why and how race is important, but he continued to search for a neutral way to argue for the importance of race without finding race to be important as a perspective in and of itself. Race is not only unconscious in the Lawrence sense, but it is conscious in that all of the participants in the legal system begin their arguments with the perspective of the white majority. This is precisely what Black Jurisprudence must change if law is to be a more effective tool for eradicating discrimination in the future.

Lawrence's excellent article is not the only part of the movement toward a Black Legal Scholarship that is unwilling to make that leap of faith necessary to appreciate and use blackness. In some ways, Professor Patricia Williams comes closest to making the necessary leap of faith in an article that is both moving and brilliant. ${ }^{175}$ She argues that blacks do not have to give up rights, but rather they must redefine them in terms that provide them to all people, rocks, cows, and trees. ${ }^{176}$ This ironic conclusion to an article that neatly understands and presents the basic elements of how black and whites think about and deal with notions of rights may be as close as we can come to transcending rights. Unfortunately, it is difficult to find a solution to these issues on the basis of Williams' redefinition. She does not provide us with a blueprint for how she came to that conclusion. One answer is that she came to that conclusion the same way that Freeman did. She accepts the notion, implicitly at the

174. See Jerome Culp, Children of the Darkness and Children of the Light: A Review of Critical Legal Studies and Race (1987) (unpublished manuscript available from author).

175. P. Williams, Alchemical Notes, supra note 158.

176. See id. at $432-33$. 
very nether regions of her consciousness, that rights exist as white Americans have defined them. Professor Williams understands that blacks have to speak their own language and need to contribute their own perspective to law and legal scholarship, but she is unable to provide a blueprint that would allow us to progress in this endeavor. Just as Freeman loses the importance of race in notions of power and class that transcend race, Williams seeks to have rights that will transcend race.

There are three things that tie together these tentative efforts toward a Black Legal Scholarship. First, all of these scholars have asked how race fits into modern legal scholarship and practice. ${ }^{177}$ Second, all of the practitioners have concluded that the existing perspective propounded by most legal scholars, particularly white scholars, lacks a black perspective. 178

Finally, most of these authors also have framed their arguments in very personal and unconventional terms. Dean Bell has turned into a novelist, whereas part of the cogency of both Professor Williams' and Professor Lawrence's arguments stems from the unconventional beginning or structure of their arguments. Like Feminist Legal Scholarship, Black Legal Scholarship must change the boundaries of analysis. These approaches to the problem are ways to deal with the first three descriptions of the history of the legal relationship of blacks in American lawignoring blacks, paternalism, and external regulation. This history limits the ability of blacks to be heard, and when they are heard, limits their language to the kind of cadences that can be understood by traditional scholars.

None of these very important efforts deal with the fourth stage of the legal relationship of blacks with the law-black Americans who participate in the legal environment deferring to the interests of the white majority. Blacks are still asked to defer their interests to those of the white majority. Those scholars, all nonlawyers, who have attempted to address these issues from a conservative perspective have made the same mistakes. The most visible person to make these mistakes is Thomas Sowell.

177. See Bell, Foreword, supra note 25; Harlon Dalton, The Clouded Prism, 22 HaRv. C.R.-C.L. L. REv. 435 (1987); R. Kennedy, A Reply to Philip Elman, supra note 5; R. Kennedy, The Tradition of Celebration, supra note 5; Lawrence, supra note 159 (contrasts psychological evidence of unconscious racism with current theoretical models of how the legal system should respond; Lawrence proposes a test that would look to the "cultural meaning" of acts to determine if a significant portion of the population thought of the government act in racial terms-if so, the Court should apply heightened scrutiny); P. Williams, Alchemical Notes, supra note 158.

178. The best example of this argument, cast in illuminating simplicity, is Randall Kennedy's comment on the work of Benno Schmidt, now President of Yale University. See R. Kennedy, The Tradition of Celebration, supra note 5. 
Sowell's argument can be divided into two parts. First, he argues that race is not an important issue for legal determinations because race is not an important factor in determining the social, legal, or economic position of black people. He concludes that race is dwarfed as an explanatory variable by other race-neutral factors-notably age, ${ }^{179}$ number of children, ${ }^{180}$ period since immigrant left rural area, ${ }^{181}$ cultural attributes, ${ }^{182}$ and geographic location. ${ }^{183}$ Second, Sowell argues that although "affirmative action" has not been effective in eliminating racial discrimination, "equal opportunity" has been successful. ${ }^{184}$

The question that should be asked of Sowell is similar to the question posed above to Professors Williams and Lawrence. Why has he adopted an argument that is not supported by the data? He is not a dupe of white interests. ${ }^{185}$ Sowell is clearly reacting against the paternalism that he finds prevalent in American academia, but his response is to adopt a special form of Black Jurisprudence. He accepts the white perspective as a given and assumes that black people will have to adapt their view of law to that perspective. If blacks are poor it is because they have been stuck with the wrong cultural values. If blacks do not excel in education at the same rate as whites, he argues that it is because they have been pushed too fast into the wrong programs by liberals attempting to paternalistically help black people. Sowell concludes that the law and the economic systems are fair to black Americans because they are fair to whites and occasionally to blacks. From scant data he builds an argu-

179. See Thomas Sowell, KNowledge and Decisions 257-58 (1980) (quoting Sowell, Ethnicity in a Changing America, DAEDalus, Winter 1978, at 213, 221); Thomas Sowell, MaRKets AND Minorities 10-13 (1981); Thomas Sowell, The EConomics AND Politics of RACE 189-91 (1983).

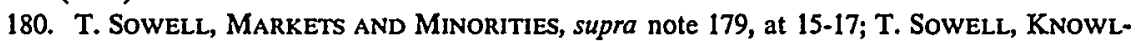
EDGE AND DECISIONS, supra note 179, at 81-113.

181. Thomas Sowell, Three Black Histories, in AMERICAN ETHNic Groups 48-49 (Thomas Sowell ed. 1978).

182. Id.

183. T. SowELL, supra note 36 , at 13-15.

184. Sowell is systematically wrong about both of these points. Within the limited scope of this paper it is not possible to examine all of the things that Sowell identifies as more important than race. For Sowell's argument that equal opportunity has been effective, see Thomas Sowell, Are Quotas Good for Blacks?, 65 COMMENTARY 39, 39-43 (June 1978). But see T. Sowell, supra note 36. Walter Williams, an economist, has also written extensively, if not well, about these legal points. His contribution to describing how one ought to look at race can be summarized in this quote:

Throughout ... discussion[s] of race, runs the common theme: There are collective forces that seek to deny blacks socioeconomic opportunity which must be offset by some other force in order to give blacks equal chances. It is this general intellectual thrust that will be challenged throughout this book. Does group socioeconomic progress depend upon whether the general society likes or dislikes the group in question?

Walter Williams, The State Against Blacks 2 (1982). In short, race matters to Williams only to the extent it is a proxy for something important that is being masked by race.

185. See, e.g., Sowell, Three Black Histories, supra note 181. 
ment for a world im which race is irrelevant-despite the tremendous amount of data to suggest that race matters now more than ever in determinimg the place of black Americans in our society. Sowell grapples, as do so many others, with the wrongly-held view that race ought to be wholly unimportant. Race neutrahty may be the right goal, but our legal system cannot achieve that goal now, nor does it appear to provide a future path to legal and economic equality for black people.

\section{CONCLUSION}

$[\mathrm{H}] \mathrm{e} .$. . was no longer a Black Aesthetician. In fact, he had written more than one essay suggesting that the legacy of that aesthetic-its defensive chauvinism and mystical reliance on "race"-was detrimental to the progress of both black literature and criticism. ... In the ranks of the Black Aesthetic, what occurred during the mid-seventies was a slip behind the back of consciousness. ... Such slips are unobserved transformations of self in the dialectics of the spirit. The charge of apostasy leveled at any former meinber of the Black Aestlietic lias, often, been merely a stunned response to his objectification of one's other self emergent from the blind side of one's own spirit. The apostate-lo-and-beloold-is simply one's "self-already-moved." ... I know that what I, hike the poor pilgrim traveler of the sorrow songs, found in my movement away from the Black Aesthetic was that the voyage out is, always already, the journey back. ${ }^{186}$

Legal Scholarship is black to the extent that it raises and deals with the black condition in American society from a black perspective. American legal scholarship occasionally has dealt with black concerns; however, this treatment has almost universally been from the perspective of the white majority. Black views are ignored and their concerns are subordinated to overriding issues of how black questions impact on white rights. To paraphrase Kenneth Stampp, to the proponents of Black Jurisprudence the question is simply how to create a legal system that considers blacks to be "white men with black skins, nothing more and nothing less." 187 This view, as I have noted above, does not deal signifi-

186. Houston A. Baker, JR., Afro-American Poetics 140-43 (1988).

187. Kenneth Stampp, The Peculiar Institution: Slavery in the ANTE-Bellum South at vii (paperback ed. 1956). This phrasing of the issue caused some controversy in the historical literature, but Stampp notes:

I did not, of course, assume that there have been, or are today, no cultural differences between white and black Americans. Nor do I regard it as flattery to call Negroes white men with black skins. It would serve my purpose as well to call Caucasians black men with white skins. I have simply found no convincing evidence that there are any significant differences between the innate emotional traits and intellectual capacities of Negroes and whites.

Id. at ix. See David Davis, Slavery and the Post-World War II Historians, in Slavery, ColonialISM AND RACISM 1-10 (Sidney W. Mintz ed. 1974) (examining the influence of Stampp's Peculiar Institution on the development of scholarship examining slavery). 
cantly with the other problems created by the differential and discriminatory treatment of blacks in the American legal system. ${ }^{188}$ Blacks are subjected to differential treatment at almost every level of society because of the color of their skin. This differential treatment will not disappear if we ignore race. The problem is not simply that race matters to those who treat blacks differently. Race matters in almost as many important ways to those who would like to have blacks treated equally. But the proponents of equality have concluded that equality should be on white terms.

If one adopts the full panoply of new tools provided by Black Legal Scholarslip to the task of interpreting the Constitution, it is clear that race matters in the present Supreme Court's interpretation. More importantly, the justices often are unaware of how race matters or when it should matter.

An additional view needs to be addressed-the concern that Black Legal Scholarship is an inappropriate perspective. In this view, white people helped to form this country, and they have a right to determine the contours of its growth and development. Black people are not meant to be treated differently, at least formally, but they should understand that this is a white country. ${ }^{189}$ This view is wrong and it is wrong for the very reason that it is attempting to create tacitly what it denies explicitly. Constitutional rights were created to prevent those in London who did not understand the concerns of the colonists from destroying important American values. Black people ask only that they be part of the formation of law and constitutional protections.

188. Others will, of course, question this conclusion. There is some evidence at least in the area of religious faith and belief that the African past of the black slaves of America significantly impacted white as well as black Americans in the antebellum South. See MeChal SOBEL, ThE WORLd They MAde Together: Black and White VAlues IN EIGHTEenth-Century ViRGINIA (1987). I do not contend that there is no black influence on the law, but that this influence is almost never acknowledged and even when it is, the scope and importance of the black impact is both underestimated and misunderstood.

189. There are several analogous arguments made by movement conservatives about other situations. This argument is the moral equivalent of the argument made by Senator S.I. Hayakawa, who said about the Panama Canal, "It's ours. We stole it fair and square." Stanley Meisler, Combat in Panama: Panamanians Have a Long History of Dependence on U.S., Los Angeles Times, Dec. 21, 1989, at A7, col.1. Many people believe that white Americans justly deserve credit for this enduring constitutional history and that they should not have to be subject to the vagaries of a black culture derived from black cultures in Africa that produced Idi Amin and cannibalism. This, of course, ignores the rather recent products of Western culture, which include the genocide of the Jews by Germany and the dropping of the atomic bomb on nonwhite Japan to end the war. Just as all black people and cultures are not responsible for dictatorship or cannibalism, Western culture is not responsible for all of the evils of the 20th century. The West, of course, does not have a monopoly on truth and justice and if it is to reach its potential it will have to learn from other cultures. 
A final question should be addressed by this Article: Whether a Black Legal Scholarship is consistent with the Constitution as an antifactional docuinent. One of the great victories in the constitutional convention was that the document would be read as limiting the ability of factions to exist and to doininate the government. Cass Sunstein has recently described the issues presented by this constitutional compromise. ${ }^{190}$ Sunstein argues that unlike mucl current political theory, the Framers did not look at the world through the lenses of pure private interest. They, in fact, thought they had killed interest as a separate issue when they adopted the Constitution. ${ }^{191}$ Can Black Legal Scholarship be made consistent with this constitutional vision? The Constitution attempts to eliminate factions by arguing for ways of eliminating the need for faction and by substituting the need to create the public good. I believe that race is really a faction that the Constitution always has included in its balancing. The task for judges, lawyers, and students is not to ignore faction but to understand low it shapes our legal world and is already included in the Constitution. Our role as scholars is to be faithful in our scholarship to the racial reality that exists in the law. All of us in our work bring our assumptions and our being to the computer terminal. The coinputer may not know our race but our words, actions, and speculations are a direct product of the racial role we play. White scholars can either play master to our role as legal scholarly mammies, or they can help us to develop roles for black and white scholars that deal with our existence inside current legal regimes. In any case, black legal scholars are beginning to make that difficult journey from mammy to militant and back again. Along the way they may begin or end as apostate, but they must begin to travel this path and they must follow wherever it leads. Black American legal scliolars are beginning to speak a chant that cannot be ignored.

\section{EPILOGUE ${ }^{192}$}

[A mythical conversation in Duke Law School Faculty Lounge shortly after Toward a Black Legal Scholarship was completed and circulated.]

190. Cass Sunstein, Interest Groups in American Public Law, 38 STAN. L. REv. 29 (1985).

191. The Framers went out of their way to eliminate the need for parties, but of course the notion of parties has persisted and grown at least until recent times. In some sense, parties are the most durable aspect of the American republic. Blacks and women and the nonpropertied have obtained the franchise, states lost their representation in Washington with the direct election of senators, and the balance of power between the president and Congress, and state and federal institutions have all changed, but the notion of two parties representing approximately the same interests has endured for almost the entire history of the country.

192. In the original version of this Epilogue I included names of my colleagues who I had thought of when I created this fictional conversation. Although almost everyone I included in this 
[FIRST White Colleague]: I just finished Black Legal Scholarship. You've started something that will change how I teach con law and constitutional history-

[JEROME CULP]: Thanks, you can't imagine how much work I put into that-

[First White Colleague]: But I wonder whether most of my colleagues will to have a dog in this fight.

[JEROME CULP]: I don't know what you mean. I spent seventy pages and two hundred footnotes showin', as they say on the street corner, that American law is the history of black people. For your colleagues to say they do not want a dog in that fight is to ignore what the fight is about.

[SECOND WHITE COLLEAGUE]: Haven't you altered your constitutional law class because of Catharine MacKinnon, 193 and Martha Minow? 194

[THIRD WHITE COLLEAGUE]: All of us have been influenced by the reminder that we do not have a single experience, but I am not quite sure how I should do Black Legal Scholarship. Black concerns are explored in my criminal law course-but I take it that's not Black Legal Scholarship.

[JEROME CULP]: That depends on the content of the discussion and the level of the issues that are explored. I am asking you to take a 90 degree change in the perspective you use to teach legal questions.

[THIRD WHITE COLLEAGUE]: Even if you can re-educate the previously uninitiated in the teaching of Black Legal Scholarship-

[JEROME CULP]: For many an impossible task-

[THIRD White ColleAGUE]: I'm still not convinced that I know the blueprint for how to be a Black Legal Scholar.

[FIRST White COLLEAGUE]: I can see you as [nodding at Culp] the black pied piper of the legal community blowing a New Orleans' horn-as the white intellectually ignorant learn new moves.

[chuckles]

discourse gave me approval to use their names, I removed the actual names because I thought that there is a certain quality of forced good humor associated with the use of the actual names. However, because one of the purposes of this Article and this Epilogue is to open conversation, and since I often engage in conversations of this type with my colleagues, I hope that this conversation will be read in that spirit.

193. See C. MACKINNon, supra note 80. Catharine MacKinnon, a white, female professor of law at the University of Michigan, has been an outspoken critic of the treatment of women in the law.

194. See Martha Minow, The Supreme Court, 1986 Term-Foreword: Justice Engendered, 101 HARV. L. Rev. 10 (1987). Martha Minow is a white woman, a Harvard Law School professor, and a leading constitutional expert and a feminist. 
[THIRD WHITE COLLEAGUE]: I am willing to be convinced that I could have written differently about the grand jury or on the management function of the courts, but how to do Black Legal Scholarship is to me still inchoate.

[FouRTH WhIte Colleague]: I don't think that there can be a black legal income tax law or a black economics separate from white economics. Should blacks have additional deductions to take account of racism? Or should there be a longer period for blacks to file their returns because many of their ancestors were slaves?

[JEROME CULP]: I don't know if blacks should have more deductions than whites, I haven't made a detailed study of how the income laws impact blacks.

[Fourth White Colleague]: Not enough is known. Certainly, we could help to do more and better studies on blacks and income taxes, but I take it that is not Black Legal Scholarship.

[SECOND White COLLEAGUE]: There aren't very many blacks who teach tax law or who do research in that area. Is that part of your point?

[JEROME CULP]: Yes. But my point is more complex. My tax colleagues have stated these arguments in their most negative terms. There may be a income tax problem that would benefit from being viewed in a black perspective, but until you look, how will anyone know? To what extent have our tax laws been distorted now and historically by the question of slavery and continuing racism? Certainly taxation issues were included in the constitutional concerns about how slaves as property would be treated.

[FIFTH WhIte Colleague]: I teach about Bob Jones. ${ }^{195}$ However, the notion you attribute to Black Jurisprudence I find a more attractive starting point for discussions of these issues because it treats everyone the same.

[JEROME CULP]: It does if you have the wherewithal to hire a tax lawyer and the good fortune to not be shoved into a disconcerting position because you are black.

[SiXth White Colleague]: Isn't that just Critical Legal Studies in blackface?

[SEVENTH WhITE COLIEAGUE]: Watch out, you are about to be flushed out of the-Augean Stables we call this law school.

[laughter]

195. Bob Jones Univ. v. United States, 461 U.S. 574 (1982). 
[SIXTh White Colleague]: How do you differ from Alan Freeman 196 or others who have written on black concerns in that movement? They believe, if I read them correctly, that they have incorporated your concerns into their perspective. Are you trying to put a more conventional, indeed conservative, covering over the same arguments?

[JEROME CULP]: No, No, No. I sometimes wonder if that dog referred to by my colleague [First White Colleague] or law professors can hunt at all. What are we teaching in our law school classes if it doesn't include black perspectives? The whole point of my article is that there are different orientations for the law, but if my colleagues can't see the point, how will the students?

[SEVENTH White Colleague]: If you lie down with dogs and law professors, particularly law professors, you are likely to rise with fleas. American law teachers are unlikely to adopt your approach precisely because they fear the little infestations that will arise with such an infatuation with Black Legal Scholarship.

[EIGHTH WhITE COLLEAGUE]: Isn't the point, Jerome, that if you are right, there is no stopping point? If I am to include Catharine MacKinnon in my Constitutional Law course, why not Phyllis Schlafly 197 or, if I am to assign Jerome Culp, why not Thomas Sowell? 198 Sowell has written on some constitutional law issues and he, too, has an economic perspective and he is black. If I include only Sowell or Schlafly, is that sufficient to represent the black and feminists interests, or should I simply assign Stanley Fish? ${ }^{199}$ He could represent both the feminist and black critical scholarship. In any case, as I read the Constitution, these perspectives are not illegitimate, they just do not help the court or law professor understand the issues. The best way for courts to put race behind them is to put it behind them. Race matters in the same way and to the same degree that a whole

196. See Alan Freeman, Legitimizing Racial Discrimination Through Antidiscrimination Law: A Critical Review of Supreme Court Doctrine, in CRITICAL LEGAL STUDIEs 120 (Allan Hutchinson ed. 1989). Alan Freeman is a white male law professor now at SUNY-Buffalo, and one of the early participants in the critical legal studies movement. He has written powerfully about racial discrimination.

197. Phyllis Schlafly is a white female lawyer, a housewife, and conservative opponent of many feminist concerns, and she has been head of the Eagle Foundation, a conservative legal pressure group.

198. See Thomas Sowell, Preferential Policies: An 1nternational Perspective (1990). Thomas Sowell, now a senior researcher at the Hoover Institute, is a leading black conservative economist. He has written numerous books on a range of issues, including affirmative action and how law functions.

199. See Stanley Fish, Doing What Comes Naturally: Change, Rhetoric, and the Practice of Theory IN Literary and Legal. Studies (1989). Stanley Fish is a white male professor of English and Law at Duke University. Professor Fish has been in the forefront of bringing critical theory into legal discussions. 
host of issues matters. The proper way to eliminate them is not go back to some Meesian original intent, but to go forward, understanding the values that our Constitution has, sometimes imperfectly, incorporated in its provisions.

[JEROME CULP]: The issue is not putting a black in your course but understanding that there are some common reference points for all blacks in thinking about the law and legal change. It would not be improper for someone to come to your view on interpretation of the Constitution based upon the principles of Black Legal Scholarship, though I think it is very unlikely, but they have to travel a different road to reach that point that you advocate.

[SIXTH White Colleague]: You don't deal with Randall Kennedy's argument ${ }^{200}$ that there is no such thing as Black Legal Scholarship. Hasn't he shown that this effort is fruitless?

[JEROME CULP]: We all bring our experiences to our writing. Certainly, if we look at Randy's body of work, it is part of what I would call Black Legal Scholarship. He has not proven to me that Black Legal Scholarship cannot or should not exist. Randy's critique misses the point of this conversation. Saying that there are not enough blacks with the requisite skills who are doing scholarship-the pool problem-does not deal with the larger issue that race matters in shaping the pool and in what we value. You are having this conversation with me precisely because my race matters. If I agree with Randy Kennedy, it means more than if some of my white colleagues agree. That is the part of what Black Legal Scholarship brings to legal scholarship. Black perspectives can and should help us to learn and to teach others just as much as white perspectives can and should do the same thing.

[BLACK COLLEAGUE]: I believe your article advances our understanding of the problems inherent in legal scholarship and the poverty of racial understanding that scholarship reflects. But weren't you really talking to two different audiences when you argue for the adoption of a Black Legal Scholarship and for the inclusion of blacks in legal teaching and writing? One argument is likely to be directed at the primarily black group of law professors who write about how the law uses and abuses black Americansthose you exhort to go out and do Black Legal Scholarship. The other part of your article is addressed to all law teachers and students-primarily white-whom you ask to incorporate more of the black perspective in understanding and interpreting the law and the Constitution. Aren't those

200. See R. Kennedy, supra note 12. Randall Kennedy is a black male professor of Law at Harvard Law School. He has argued that minority scholars have not proven their criticism about the legal academy. 
really conflicting goals, and aren't your messages to both audiences likely to be lost in the effort to include both of them in the same article?

[JEROME CULP]: In order to have black scholars taken seriously and Black Legal Scholarship adopted, it is necessary to legitimate it-just as in some sense you and a small group of others help to legitimate the role of blacks in legal history and the role of black scholars in that interpretive process. Blacks have to convince both themselves and their white colleagues and students that their view of the law is important and can play a role in legal interpretation. This has to be done simultaneously. To bifurcate the process is to lose whatever chance there is of actually doing either. If black scholars who worry about Black Legal Scholarship are not convinced that it is alright to include it in their classes, then they will be Stanfordized ${ }^{201}$ by their students and colleagues.

[NINTH WhITE COLLEAGUE]: I read your article carefully; and you argue that blacks see the world differently. Does this mean that only blacks can do black scholarship? Some white judges seem to have been more concerned with issues that you describe as Black Jurisprudence and Black Legal Scholarship than some black judges.

[JEROME CULP]: I was recently reading David Walker's Appeal which was seen by the South as a direct appeal for revolt by the vast black population. David Walker was a black abolitionist of the early 1800s. Walker replied to the racism in Jefferson's Notes on the State of Virginia, ${ }^{202}$ in particular to the argument that since the Greek slaves were men of substance in the sciences and the arts that the problem of blacks was not a white-imposed condition of black Americans, but was a product of nature. I have it here; I'll read it to you. Walker said,

For let no one of us suppose that the refutations which have been written by our white friends are enough-they are whites-we are blacks. We, and the world wish to see the charges of Mr. Jefferson refuted by the blacks themselves, according to their chance; for we must remember that what the whites have written respecting this subject, is other men's labours, and did not emanate from the blacks. I know well, that there are some talents and learning among the coloured people of this country, which we have not a chance to deyelope, in consequence of oppression; but our oppression ought not to hinder us from acquiring all we can. For we will have a chance to develope them by and by. God will not suffer us, always to be oppressed. Our sufferings will come to an end, in spite of all the Americans this side of eternity.

201. This refers to the incident at Stanford Law School in which Derrick Bell was convinced to participate in a series of lectures that, unbeknownst to him, were to supplement his "inadequate" teaching of constitutional law.

202. Thomas Jefferson, Notes on the State of Virginia (William Peden ed. 1954) (1787). 
Then we will want all the learnings and talents among ourselves, and perhaps more, to govern ourselves.- "Every dog must have its day," the American's is coming to an end. 203

Everyone has to do black scholarship if it is to succeed. My article is about starting a conversation about that process so that blacks in legal situations can truly have their day-in order to make the American dream include black people and their ambitions.

203. David Walker, Appeal to the Colored Citizens of the WORLd, BUt IN ParticuLAR, AND VERY EXPRESSLy, TO THOSE OF THE UNITED STATES OF AMERICA 14-15 (Charles Wiltse ed. 1965) (1829). 